\title{
ヒト胎児胸部交感神経幹わよび幹神経節の 形態学的検索について
}

\author{
野村 利夫 \\ 日本医科大学第 2 解剖学教室 (主任 : 吉川文雄教授)
}

\begin{abstract}
A morphorogical investigation of the thoracic sympathetic trunks and the chain ganglia of human fetuses
\end{abstract}

Toshio Nomura

The Second Department of Anatomy (Director: Prof. Fumio Kikkawa), Nippon Medical School

The present investigation was made to elucidate the anatomical features of the thoracic portion of the sympathetic trunks, their ganglia, and their rami communicantes in fetuses.

Twenty thoracic sympathetic trunks in ten fetuses, $5 \sim 6$ months old, were studied. The results obtained were as follows;

1) The total number of ganglia in the thoracic sympathetic trunks in ten fetuses was 206 and the average number of ganglia was 10.3 in the thoracic portion of the trunk.

2) On the ventral side of the neck of the first rib, the first thoracic ganglion was fused with the inferior cervical ganglion to form the stellate ganglion on both sides in all of the ten fetuses. In one of these ten subjects the stellate ganglion was further fused with the second thoracic ganglion. The stellate ganglia were classified into three types according to shape; Type I, II, and III. The most frequent type was Type I, the cylinder shape, which was found in 9 out of 20 (45\%).

3) The ganglia below the second thoracic ganglion, 186 in total, were classified into nonfusional and fusional form ganglia. The nonfusional form ganglia, 153, were further classified into 5 types according to shape, of which the most frequent was the trianguler type, 77 of 153 (50.3\%). The fusional form ganglia, 33, were again classified into 4 types according to shape. The most frequent of them was Type II where one ganglion makes a contact with the other without any narrow segment at the juncture. The incidence of such type was 14 of $33(42.4 \%)$.

4) Fourteen cross communications between the right and the left sympathetic trunks were confirmed in 8 out of 10 fetuses.

5) All of the thoracic rami of thoracic spinal nerves had rami communicantes, connecting with sympathetic trunks. The number of rami communicantes was 3 on the average. The more caudally ventral rami were located, the less the number of rami communicantes became.

6) Rami communicantes to the dorsal rami of the thoracic spinal nerves were confirmed in 148 out of 240 thoracic spinal nerves corresponding to the spinal cord segments (61.7\%).

7) Rami communicantes to the meningeal branches of the thoracic spinal nerves were confirmed in 51 out of 240 thoracic spinal nerves corresponding to the spinal oord segments (21.3\%).

8) Four ganglia intermedia were confirmed on the rami communicantes to the ventral rami of the eleventh and twelfth thoracic spinal nerves.

Key words : trunks sympathicus, ganglion stellatum, rami communicantes, ganglia trunci sympathici

Present address : The Second Department of Anatomy, Nippon Medical School, 1-1-5, Sendagi, Bunkyo-ku, Tokyo, 113 Japan 


\section{緒 言}

腰痛と交感神経交通枝との関連性について Nathan $(1968)^{12}$ は, 臨床解剖学的に変形性脊椎症に打ける骨 棘による交感神経交通枝圧迫の問題をとり上げ, また

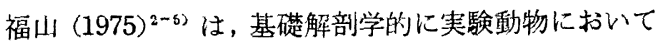
末梢神経の扇形細裂標本法を用いて自律神経の形態学 的および機能的分析を行った結果「腰部交感神経幹の 中には 30 50\% におよぶ求心性線維が含まれてお り，この部における椎間板へルニアなどにより交感神 経を刺激して腰痛惹起の原因となり得る」と指摘した。 このことに関して当教室の迫田 $(1983)^{6)}$ は，本邦人 胎児死体の腰部交感神経幹の形態学的特徽について検 索し報告したが，今回著者は，体幹胸部における交感 神経幹について調査を行ったので追加報告する. ちな みに胸部交感神経幹の形態学的検索報告は,わずかに 松井 ${ }^{7)}$ ，松島帛， Atumi ${ }^{9)}$ および前田ら ${ }^{10,11)}$ の報告が あるにすぎない。

\section{研究材料および方法}

日本医科大学第 2 解剖学教室所蔵の胎児死体 10 体 (5 6 6 月月齢) を用い両側胸部交感神経幹の走行およ び吻合枝, 交感神経節の形態, 交通枝の数および走行 について検索した，観察は Nikon および Wild の実 体顕微鏡下に行い， 交感神経節の大きさについては Fusoh の Digital 測定顕微鏡を用いた. なお写真撮影 は，Wild の microphoto を用い，検索所見の記録は 剖查の進行経過に従って遂次局所のスケッチおよびカ ラー写真撮影を行った.

\section{成 績}

\section{1. 胸部交感神経幹の走行状態について (Photo 1,} 2)

一般に成書12 21) では，交感神経幹は䅡部では椎体 の近くに, 胸部ではやや外方に扁して肋骨頭の前側 に, 腹部では再び椎体に近接して見られると記载され ている. 著者の観察所見では, 交感神経幹は䅡部から 胸部に移行する部位で方向を変へ背方へと向かい第 1 肋骨頭に達するが、この前面において全例両側に第 1 胸部交感神経節は下頝神経節と合して星状神経節（頝 胸神経節）を形成していた，次いで下方に向かい第 2 以下の胁骨頭に接し, 椎体の側面に密着しながら第 11 または第 12 胸部交感神経節の位置に達すると交感 神経幹は胁骨頭を離れ，椎体の前面中央部に向かって
移動する傾向がみられた。

\section{2. 胸部交感神経節の出現数について}

胸部交感神経節の上界は，第 1 胸部㛭哊神経と交通

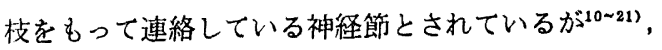
今回の著者の検索では全例両側に星状神経節の形成が 観察されたのでこれを上界とした. 下界については松 島臭) および西村 ${ }^{28)}$ 亿従い第 12 胸部春娟有神経と交通 枝をむつ神経節のうち，交通枝の走行状態および神経 節と椎体との位置関係（第 11 胸椎から第 1 腰椎上に 存在する神経節)とを併せて基準として第 12 胸部交 感神経節を同定しこれを下界とした. なお庱合型交感 神経節（後述）はこれを 1 個と算定した.

出現数は Table 1 に示すごとく総数 206 個で平均 は 10.3 個（片側）であった. 最も多かったのは㭘索 例 No. 4 (Plate 4), No. 6 (Plate 6) のそれぞれ 左側で 12 個, 最も少なかったのは検索例 No. 7 (Plate 7) の左侧で 8個であった. ちなみに成人およ び胎児についての先人の報告は 10〜12 個であっ $た^{7 \sim 11)}$. 考察の項で述べるが胸部交感神経節の個数は 癄合型交感神経節の出現数およびこの癄合型交感神経 節を 1 個として算定するか，分離して算定するかとい

Table 1 Number of ganglia in the thoracic sympathetic trunk

\begin{tabular}{crr}
\hline Case number & $\mathrm{R}$ & $\mathrm{L}$ \\
\hline 1 & 11 & 10 \\
2 & 9 & 9 \\
3 & 10 & 10 \\
4 & 11 & 12 \\
5 & 11 & 9 \\
6 & 11 & 12 \\
7 & 11 & 8 \\
8 & 9 & 10 \\
9 & 11 & 11 \\
10 & 10 & 11 \\
\hline Total & 104 & 102 \\
Total (R+L) & 206 & \\
\hline Average (R+L) & & 10.3 \\
\hline
\end{tabular}

Table 2 Number of types of ganglia in the thoracic sympathetic trunk

\begin{tabular}{lrrr}
\hline \multicolumn{1}{c}{ Ganglia } & $\mathrm{R}$ & $\mathrm{L}$ & \multicolumn{1}{c}{ Total } \\
\hline Stellate & 10 & 10 & $20(9.7 \%)$ \\
Nonfusional form & 76 & 77 & $153(74.3 \%)$ \\
Fusional form & 18 & 15 & $33(16.0 \%)$ \\
\hline \multicolumn{1}{c}{ Total } & 104 & 102 & 206 \\
\hline
\end{tabular}


う問題と，第 12 胸部交感神経節の同定の方法によっ ても相違が出てくるものと思われる.

Table 2 に示すごとく 10 体 20 側での胸部交感 神経節は総数 206 個で，その内わけは星状神経節が 20 個 (9.7\%), 非疻合型交感神経節が 153 個 (74.3 $96)$, 癒合型交感神経節が 33 個 (16.0\%) であった。

\section{3. 星状神経節（頝胸神経節）について}

(1) 出現数

成書 ${ }^{12-21)}$ には第 1 胸部交感神経節は大きく，しば しば第 2 胸部交感神経節とともに下頝神経節と合して 星状神経節を作ると記载されている. 著者の検索では 全例両側に合計 20 個が観察された.

(2) 形状 (Photo 3, 4)

星状神経節は種々の形態を呈するが，今回著者はこ れを Fig. 1 のごとく 3 型に分類した.

Type I : 円筒形型 (南瓜型, 卵円形型など不均等
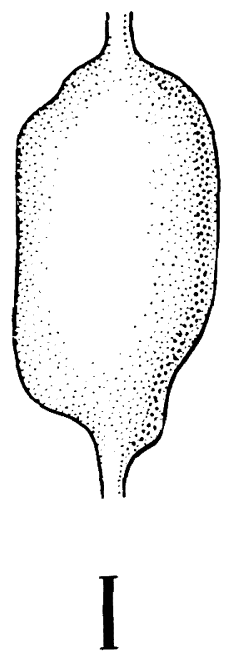

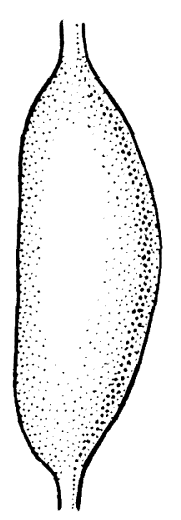

II
な直径のものも含む)

Type II : 不正長方形型

Type III：ひょらたん型（中央部に明らかなくびれ のみられるもの)

各 Type の出現数は Table 3 に示すごとくであ った.

（3）大きさ

星状神経節の大きさを測定し長径 $\times$ 短径で表した。

Table 4 のごとく大きさの平均は $5.39 \times 2.09 \mathrm{~mm}$ で 最大は Type III $9.25 \times 2.29 \mathrm{~mm}$, 最小は Type II

Table 3 Number of stellate ganglia

\begin{tabular}{cccc}
\hline Type & R & L & Total \\
\hline I & 4 & 5 & $9(45 \%)$ \\
II & 2 & 3 & $5(25 \%)$ \\
III & 4 & 2 & $6(30 \%)$ \\
\hline Total & 10 & 10 & 20 \\
\hline
\end{tabular}

Fig. 1 Classification of stellate ganglia

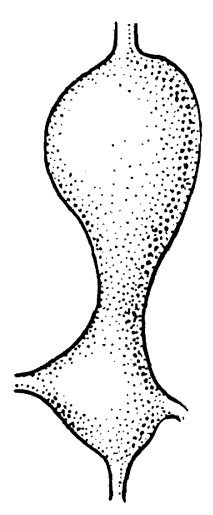

III

Table 4 Average size of stellate ganglia

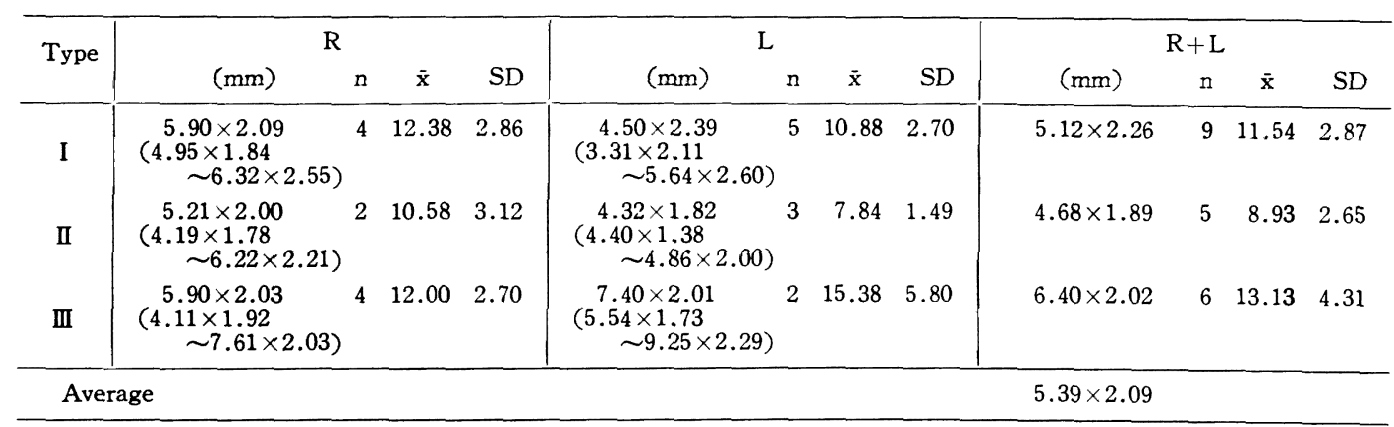

$\mathrm{n}=$ Number,$\overline{\mathrm{x}}=$ Average, $\mathrm{SD}=$ Standard Deviation 


$$
-66-(432)
$$

の $4.40 \times 1.38 \mathrm{~mm}$ であった.

\section{4. 非瘾合型交感神経節について}

交感神経節は節間枝によって上下に連絡している が，時には節間枝の消失している部位が観察された。 この部位では上下の交感神経節は直接連絡し瘉合して いることになる.はなはだしい時には 3 個の神経節が 癒合したとみられる長方形のかたまりが観察された.

著者はこれらの神経節を癒合型交感神経節とし, 独立 して存在する神経節を非癒合型交感神経節として分類 した. 以下は非癒合型交感神経節の主要所見である.

(1) 出現数

非癒合型交感神経節は右側 76 個, 左側 77 個で合
計 153 個観察された（Table 2). これを高位別にみ ると Fig. 2 に示すごとくTh 4 位およびTh 5 位と Th 11 位および Th 12 位では出現数が少なかった.

(2) 形状

非癒合型交感神経節の形は多様で松井 ${ }^{7)}$, 松島 ${ }^{8)}$, Atumi ${ }^{9)}$ ，前田 ${ }^{10,11)}$ はそれぞれに細かく分類して いるが, 著者は迫田 ${ }^{6)}$ の分類に従った. Fig. 3 に示 すごとく5型に分類した（Photo 7〜10)

Type I : 長棈円形型

Type II : 三角形型

Type III : 四辺形型

Type IV : 星型

Type V : 不規則型

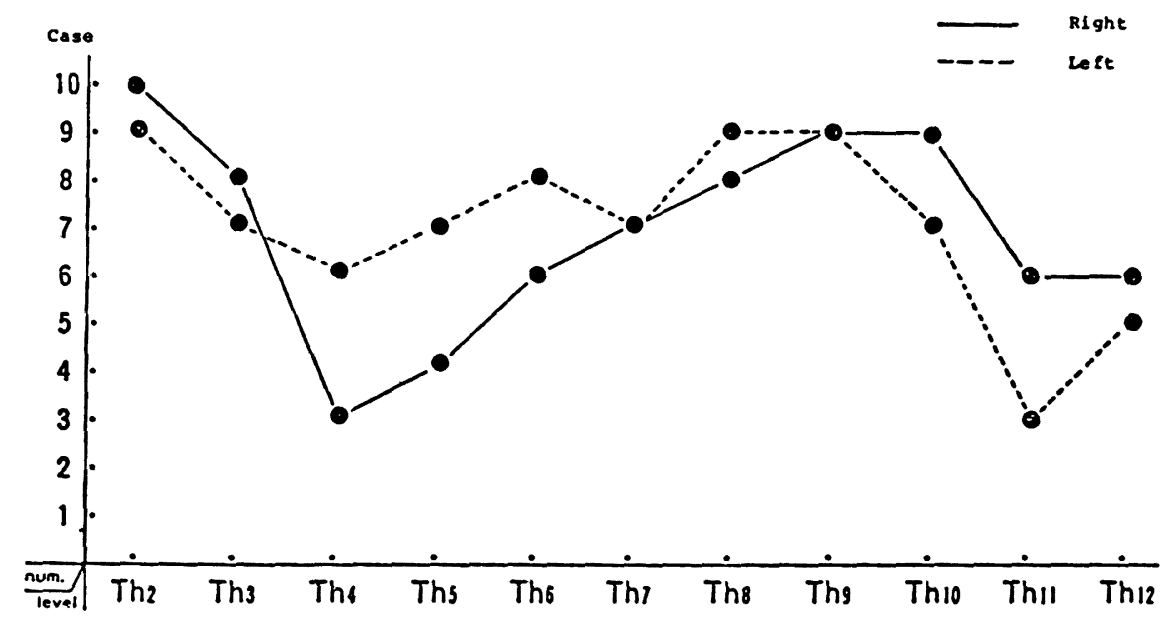

Fig. 2 Number of nonfusional form ganglia
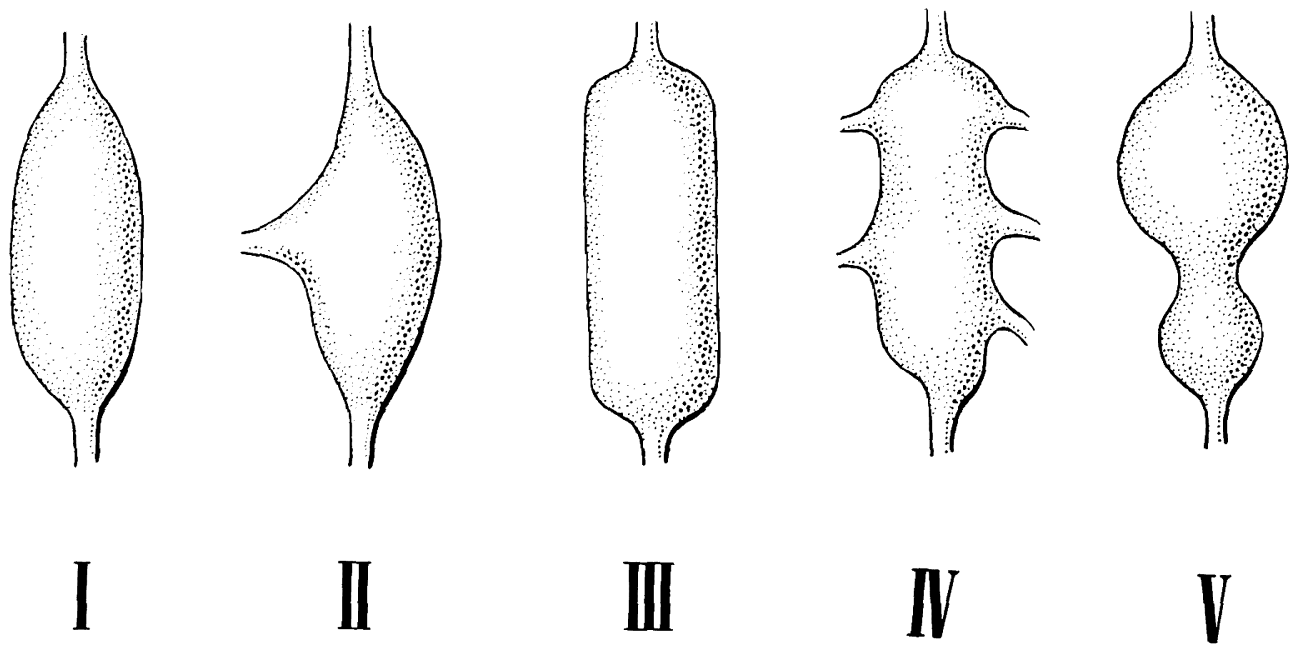

Fig. 3 Classification of nonfusional form ganglia 


$$
\text { (433) }-67-
$$

Table 5 Number of nonfusional form ganglia

\begin{tabular}{crrr}
\hline Type & R & \multicolumn{1}{c}{ L } & \multicolumn{1}{l}{ Total } \\
\hline I & 8 & 14 & $22(14.4 \%)$ \\
II & 41 & 36 & $77(50.3 \%)$ \\
III & 11 & 8 & $19(12.4 \%)$ \\
IV & 12 & 15 & $27(17.7 \%)$ \\
V & 4 & 4 & $8(5.2 \%)$ \\
\hline Total & 76 & 77 & 153 \\
\hline
\end{tabular}

各 Type の出現数は Table 5 に示すごとくであ った.これを高位別にみると Table 6 のごとくであ った.

(3) 大きさ

非瘑合型交感神経節の大きさを測定し長径 $\times$ 短径で 表した. Table 7 のごとく平均は $2.47 \times 1.59 \mathrm{~mm}$
で, 最大は Type I の $4.88 \times 1.94 \mathrm{~mm}$,最小は Type IIの $1.10 \times 0.53 \mathrm{~mm}$ であった. また，大きさを高位 別に測定した結果は Table 8 に示すごとくであった.

\section{5. 癒合型交感神経節について（第 2 胸部交感神経 節以下)}

前記したごとく第 1 胸部交感神経節はすべて星状神 経節に加わっていたので, 以下に第 2 胸部交感神経節 から下位の瘁合型交感神経節について述べる.

(1) 出現数

癒合型交感神経節の出現数は Table 9 に示すごと く右側 18 個, 左側 15 個で合計 33 個であった. こ れを高位別にみると Table 10 のごとくで中位および 下位に多くみられた.

Table 6 Nonfusional form ganglia in terms of level and type

\begin{tabular}{|c|c|c|c|c|c|c|c|c|c|c|c|c|c|c|}
\hline Type & Th & 2 & 3 & 4 & 5 & 6 & 7 & 8 & 9 & 10 & 11 & 12 & Total & Total $(\mathrm{R}+\mathrm{L})$ \\
\hline \multirow{2}{*}{ I } & $\mathrm{R}$ & 0 & 1 & 0 & 1 & 0 & 0 & 0 & 1 & 1 & 1 & 3 & 8 & \multirow{2}{*}{22} \\
\hline & $\mathrm{L}$ & 0 & 1 & 3 & 2 & 0 & 0 & 1 & 3 & 2 & 0 & 2 & 14 & \\
\hline \multirow[t]{2}{*}{ II } & $\mathrm{R}$ & 10 & 5 & 2 & 1 & 3 & 4 & 5 & 4 & 4 & 2 & 1 & 41 & \multirow[t]{2}{*}{77} \\
\hline & $\mathrm{L}$ & 7 & 4 & 2 & 4 & 2 & 4 & 4 & 2 & 4 & 3 & 0 & 36 & \\
\hline \multirow{2}{*}{ III } & $\mathrm{R}$ & 0 & 1 & 0 & 0 & 0 & 2 & 1 & 3 & 3 & 1 & 0 & 11 & \multirow{2}{*}{19} \\
\hline & $\mathrm{L}$ & 0 & 2 & 0 & 0 & 3 & 0 & 1 & 2 & 0 & 0 & 0 & 8 & \\
\hline \multirow{2}{*}{ IV } & $\mathrm{R}$ & 0 & 1 & 1 & 2 & 3 & 1 & 2 & 0 & 1 & 1 & 0 & 12 & \multirow{2}{*}{27} \\
\hline & L & 1 & 1 & 1 & 1 & 3 & 2 & 3 & 2 & 1 & 0 & 0 & 15 & \\
\hline \multirow{2}{*}{ V } & $\mathrm{R}$ & 0 & 0 & 0 & 0 & 0 & 0 & 0 & 1 & 0 & 1 & 2 & 4 & \multirow{2}{*}{8} \\
\hline & $\mathrm{L}$ & 0 & 0 & 0 & 0 & 0 & 1 & 0 & 0 & 0 & 0 & 3 & 4 & \\
\hline \multicolumn{2}{|c|}{ Total } & 18 & 16 & 9 & 11 & 14 & 14 & 17 & 18 & 16 & 9 & 11 & \multicolumn{2}{|r|}{153} \\
\hline
\end{tabular}

Table 7 Average size of nonfusional form ganglia

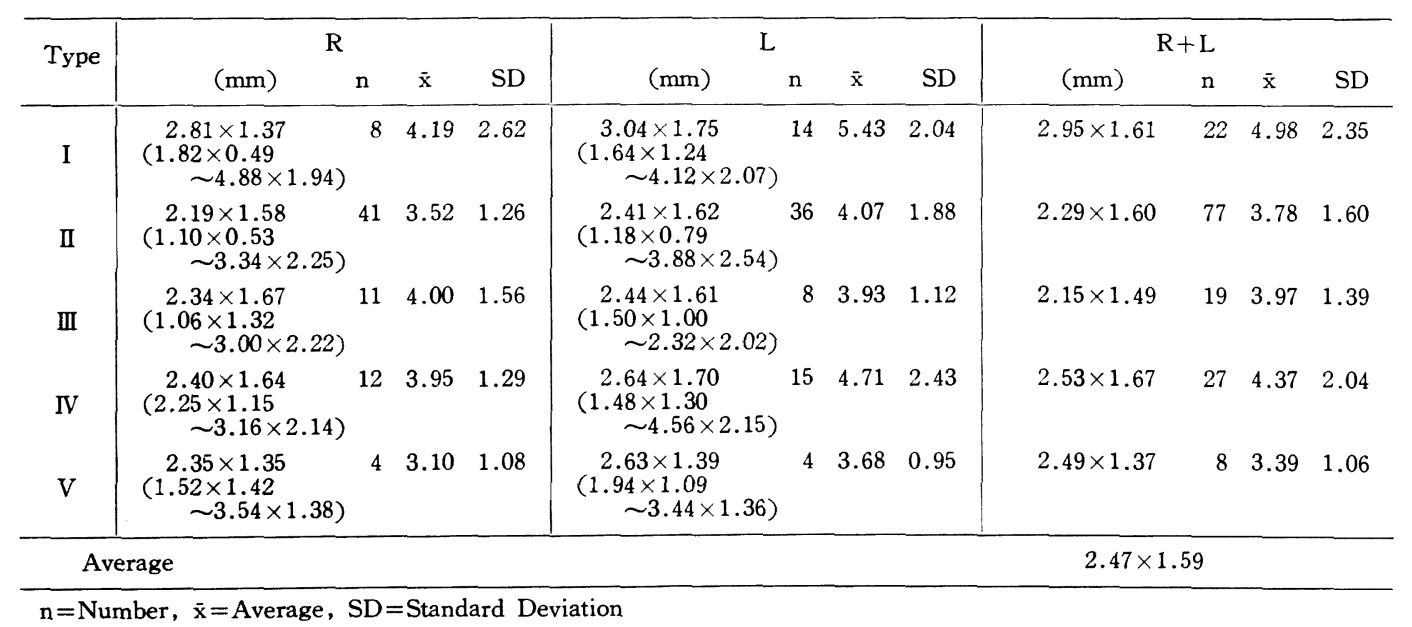

$\mathrm{n}=$ Number, $\overline{\mathrm{x}}=$ Average, $\mathrm{SD}=$ Standard Deviation 
Table 8 Average size of nonfusional form ganglia

\begin{tabular}{|c|c|c|c|c|c|c|c|c|c|c|c|c|}
\hline \multirow{2}{*}{$\mathrm{Th}$} & \multicolumn{4}{|l|}{$R$} & \multicolumn{4}{|l|}{$\mathrm{L}$} & \multicolumn{4}{|c|}{$\mathrm{R}+\mathrm{L}$} \\
\hline & $(\mathrm{mm})$ & $\mathbf{n}$ & $\overline{\mathbf{x}}$ & $\mathrm{SD}$ & (mm) & $\mathrm{n}$ & $\overline{\mathbf{x}}$ & SD & $(\mathrm{mm})$ & $\mathrm{n}$ & $\overline{\mathbf{x}}$ & SD \\
\hline 2 & $\begin{array}{c}2.36 \times 1.69 \\
(1.52 \times 1.41 \\
\sim 3.34 \times 2.25)\end{array}$ & 10 & 4.09 & 1.49 & $\begin{array}{c}2.20 \times 1.57 \\
(1.48 \times 1.37 \\
\sim 2.47 \times 2.11)\end{array}$ & 9 & 3.42 & 0.97 & $2.28 \times 1.64$ & 19 & 3.84 & 1.30 \\
\hline 3 & $\begin{array}{l}2.53 \times 1.68 \\
(2.15 \times 1.32 \\
\sim 3.00 \times 2.22)\end{array}$ & 8 & 4.27 & 1.11 & $\begin{array}{l}2.83 \times 1.69 \\
(2.17 \times 1.43 \\
\sim 3.49 \times 2.19)\end{array}$ & 7 & 4.89 & 1.57 & $2.67 \times 1.68$ & 15 & 4.56 & 1.38 \\
\hline 4 & $\begin{array}{l}2.39 \times 1.90 \\
(1.99 \times 1.52 \\
\sim 2.54 \times 2.47)\end{array}$ & 3 & 4.59 & 1.33 & $\begin{array}{c}2.99 \times 1.75 \\
(2.36 \times 1.26 \\
\sim 4.12 \times 2.07)\end{array}$ & 6 & 5.32 & 2.00 & $2.79 \times 1.80$ & 9 & 5.08 & 1.84 \\
\hline 5 & $\begin{array}{c}2.15 \times 1.49 \\
(1.79 \times 1.47 \\
\sim 2.42 \times 1.67)\end{array}$ & 4 & 3.21 & 0.52 & $\begin{array}{c}2.52 \times 1.75 \\
(1.64 \times 1.24 \\
\quad \sim 2.81 \times 2.55)\end{array}$ & 7 & 4.54 & 1.74 & $2.38 \times 1.65$ & 11 & 4.05 & 1.56 \\
\hline 6 & $\begin{array}{c}2.18 \times 1.60 \\
(1.66 \times 1.29 \\
\sim 3.08 \times 1.54)\end{array}$ & 6 & 3.50 & 0.90 & $\begin{array}{l}2.76 \times 1.91 \\
(1.50 \times 1.00 \\
\sim 3.88 \times 2.54)\end{array}$ & 8 & 5.00 & 2.36 & $2.51 \times 1.78$ & 14 & 4.69 & 2.34 \\
\hline 7 & $\begin{array}{c}2.42 \times 1.59 \\
(2.08 \times 1.13 \\
\sim 2.65 \times 2.11)\end{array}$ & 7 & 3.87 & 1.04 & $\begin{array}{c}2.85 \times 1.79 \\
(3.02 \times 1.17 \\
\sim 4.25 \times 2.07)\end{array}$ & 7 & 5.09 & 1.65 & $2.63 \times 1.69$ & 14 & 4.48 & 1.51 \\
\hline 8 & $\begin{array}{c}2.48 \times 1.50 \\
(2.21 \times 0.90 \\
\sim 3.16 \times 2.14)\end{array}$ & 8 & 3.79 & 1.31 & $\begin{array}{c}2.50 \times 1.66 \\
(1.48 \times 1.30 \\
\sim 4.56 \times 2.15)\end{array}$ & 9 & 4.32 & 2.28 & $2.49 \times 1.59$ & 17 & 4.07 & 1.90 \\
\hline 9 & $\begin{array}{l}2.19 \times 1.40 \\
(1.83 \times 0.10 \\
\sim 3.68 \times 1.56)\end{array}$ & 9 & 3.22 & 1.77 & $\begin{array}{c}2.61 \times 1.52 \\
(1.35 \times 1.29 \\
\sim 3.77 \times 2.07)\end{array}$ & 9 & 4.10 & 1.77 & $2.40 \times 1.46$ & 18 & 3.66 & 1.82 \\
\hline 10 & $\begin{array}{l}1.96 \times 1.36 \\
(1.10 \times 0.53 \\
\sim 2.76 \times 1.74)\end{array}$ & 9 & 2.79 & 1.27 & $\begin{array}{l}2.31 \times 1.40 \\
(1.18 \times 0.79 \\
\sim 3.75 \times 1.59)\end{array}$ & 7 & 3.38 & 1.49 & $2.11 \times 1.38$ & 16 & 3.05 & 1.40 \\
\hline 11 & $\begin{array}{l}2.73 \times 1.60 \\
(2.25 \times 1.15 \\
\sim 4.04 \times 1.62)\end{array}$ & 6 & 4.34 & 1.35 & $\begin{array}{c}1.58 \times 1.24 \\
(1.23 \times 0.85 \\
\sim 1.79 \times 1.46)\end{array}$ & 3 & 2.02 & 0.69 & $2.35 \times 1.48$ & 9 & 3.57 & 1.61 \\
\hline 12 & $\begin{array}{l}2.50 \times 1.19 \\
(1.82 \times 0.49 \\
\quad \sim 4.88 \times 1.94)\end{array}$ & 6 & 3.31 & 2.82 & $\begin{array}{l}3.09 \times 1.55 \\
(1.94 \times 1.09 \\
\sim 4.93 \times 1.55)\end{array}$ & 5 & 4.84 & 1.85 & $2.77 \times 1.36$ & 11 & 4.00 & 2.55 \\
\hline & e (Th 2 Th12, R & $2+I$ & & & & & & & $2.47 \times 1.59$ & & & \\
\hline
\end{tabular}

Table 9 Number of fusional form ganglia

\begin{tabular}{c|rr|r}
\hline Type & R & L & \multicolumn{1}{|c}{ Total } \\
\hline I & 3 & 3 & $6(18.2 \%)$ \\
II & 9 & 5 & $14(42.4 \%)$ \\
III & 1 & 2 & $3(9.1 \%)$ \\
IV & 5 & 5 & $10(30.3 \%)$ \\
\hline Total & 18 & 15 & 33 \\
\hline
\end{tabular}

(2) 形状

Fig. 4 に示すごとく形状により次の 4 型に分類し えた.

Type I：2 個の神経節が接着しておりその接合部 には明らかなくびれのみられるもの.

Type II : 2 個の神経節が接着しているがその接合 部にはくびれのみられないもの.

Type III : 3 個の神経節が疮合しているもの.

Type IV：1 個の神経節から上下にわたる脊髄神経 に交通枝を出すもの（同じレベルに他の 神経節がみられない場合)
これらの痹合型交感神経節の出現数は Table 9 に 示すごとくで最も多かったのは Type II の 14 個 (42.4\%)，最も少なかったのは Type III の3 個 (9.1\%) であった.

(3) 大きさ

癒合型交感神経節の大きさを測定し長径×短径で表 したところ Table 11 のごとくなった. 大きさの平均 は $4.89 \times 1.71 \mathrm{~mm}$ であった. 最大は右側の Type III で $11.04 \times 2.76 \mathrm{~mm}$ で, 最小は左側の Type IVで $1.76 \times 1.19 \mathrm{~mm}$ であった.

6. 両側交感神経幹間の吻合枝（横枝）について (Fig. 5 12, Plate 1 3, 5, 6, 8〜10)

両側交感神経幹ないし神経節間を結合する吻合枝 （横枝）について成書では，しばしば存在するが第 5 腰椎以上の高さではまれであるとのみ記載されている (Gray ら ${ }^{203}$ ). 腰部におけるこの吻合枝の存在につい ては松島(8), Webber ${ }^{24)}$ および迫田() の報告があるが 
Table 10 Fusional form ganglia in terms of level and type

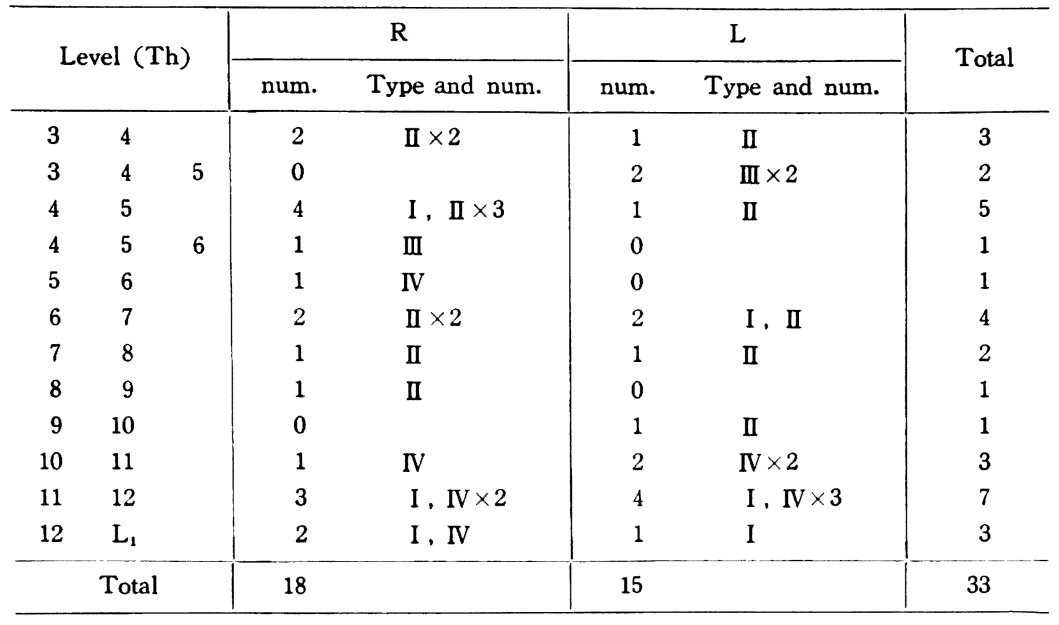
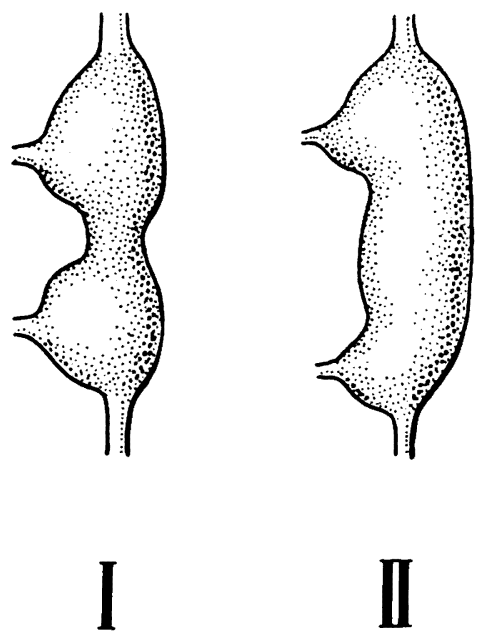
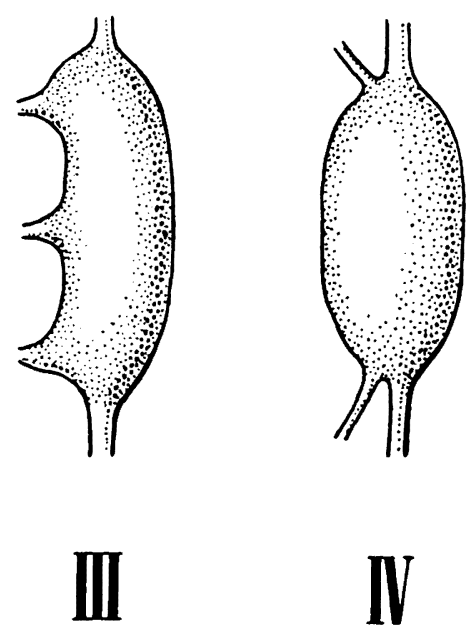

Fig. 4 Classification of fusional form ganglia (Except stellate ganglia)

Table 11 Average size of fusional form ganglia (Except stellate ganglia)

\begin{tabular}{|c|c|c|c|c|c|c|c|c|c|c|c|c|}
\hline \multirow{2}{*}{ Type } & \multicolumn{4}{|l|}{$\mathrm{R}$} & \multicolumn{4}{|l|}{$\mathrm{L}$} & \multicolumn{4}{|c|}{$R+L$} \\
\hline & $(\mathrm{mm})$ & $\mathrm{n}$ & $\overline{\mathbf{x}}$ & SD & $(\mathrm{mm})$ & $\mathrm{n}$ & $\overline{\mathbf{x}}$ & $\mathrm{SD}$ & $(\mathrm{mm})$ & $\mathrm{n}$ & $\overline{\mathrm{x}}$ & SD \\
\hline I & $\begin{array}{l}4.72 \times 1.49 \\
(3.76 \times 1.44 \\
\quad \sim 5.29 \times 1.50)\end{array}$ & 3 & 7.04 & 1.15 & $\begin{array}{l}5.04 \times 1.57 \\
(3.99 \times 1.68 \\
\quad \sim 5.36 \times 1.67)\end{array}$ & 3 & 7.83 & 0.92 & $4.88 \times 1.53$ & 6 & 7.44 & 1.12 \\
\hline II & $\begin{array}{l}4.99 \times 1.97 \\
(3.78 \times 1.82 \\
\quad \sim 7.19 \times 2.59)\end{array}$ & 9 & 10.01 & 3.46 & $\begin{array}{l}4.48 \times 1.60 \\
(3.56 \times 1.23 \\
\quad \sim 5.47 \times 2.01)\end{array}$ & 5 & 7.33 & 2.23 & $4.81 \times 1.84$ & 14 & 9.05 & 3.34 \\
\hline III & $11.04 \times 2.76$ & 1 & & & $\begin{array}{l}7.37 \times 1.82 \\
(6.47 \times 1.47 \\
\quad \sim 8.27 \times 2.15)\end{array}$ & 2 & 13.71 & 4.07 & $8.59 \times 2.13$ & 3 & 19.30 & 8.57 \\
\hline IV & $\begin{array}{l}3.94 \times 1.55 \\
(2.83 \times 1.37 \\
\sim 4.41 \times 1.80)\end{array}$ & 5 & 6.08 & 1.40 & $\begin{array}{c}3.88 \times 1.51 \\
(1.76 \times 1.19 \\
\sim 4.25 \times 2.22)\end{array}$ & 5 & 6.10 & 3.18 & $3.91 \times 1.53$ & 10 & 6.09 & 2.46 \\
\hline Ave & & & & & & & & & $4.89 \times 1.71$ & & & \\
\hline
\end{tabular}

$\mathrm{n}=$ Number, $\overline{\mathrm{x}}=$ Average, $\mathrm{SD}=$ Standard Deviation 


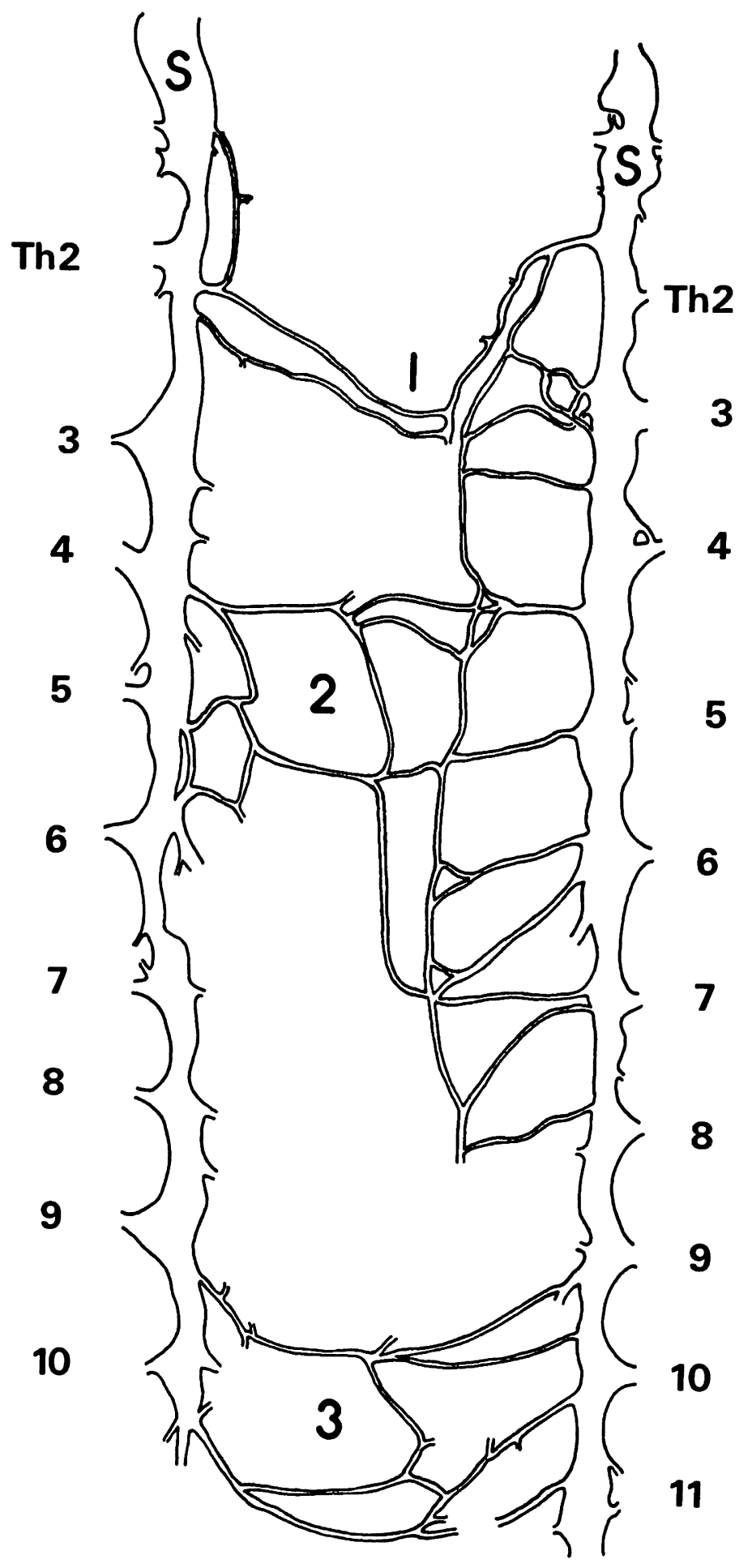

Fig. 5 Anastomosis of case No. 1 
胸部については報告がみられない，今回の著者の胸部 における検索では 10 検体中 8 体 14 部位（下記第 1 例〜第 14 例）に観察されたので各々の所見について 述べる.

第 1 例 : 検索例 No. 1 (Fig. 5 中の 1)

右側 Th 2 位より出る 2 本の横枝が斜下方に走り， 合して 1 本となり上行して左星状神経節に連絡する. なお右側起始部には，右星状神経節からの小 枝が加わっている.

第 2例：検索例 No. 1 (Fig. 5 中の 2)

右側 Th 4, Th 5, Th 6 位から出た横枝 は合して 2 本となり椎体中央部前面を横走し て左に向かい，複䧴な分枝結合を繰り返して 左側星状神経節から Th 8 位までの広い範 囲に連絡している.

第 3 例：検索例 No. 1 (Fig. 5 中の 3 )

右側 Th 9, 10 位より出た 2 本の横枝は椎 体前面中央部で上下に結合した後, さらに左 に向かって横走し左側 Th 9, 10 位に連絡す る.

第 4 例 : 検索例 No. 2 (Fig. 6 中の 4) 右側より出る横枝の起始部は複雑で星状神 経節下端から Th 4 位にまで及んでいる.こ れらの横枝は椎体前面で 3 本となり，再び分 枝結合を繰り返し左側星状神経節から Th 5 位に及ぶ広範囲に連絡する.

第 5 例：検索例 No. 2 (Fig. 6 中の 5 )

右側 Th 5, 6 位より出た 2 本の横枝は平 行して左方へと走り左側 Th 6 位から Th 8 位に連絡する.

第6例：検索例 No. 2 (Fig. 6 中の 6) 右側 Th 9, 10 位より出た 2 本の横枝は右 側内臓神経と連絡した後, 1 本となって左方 一と走り左側 Th 10 位と連絡する.

第 7 例：検索例 No. 3 (Fig. 7 中の 7 ) 両側 Th 8 位間の横位の連絡で, その経過 中に左右の内臓神経とも連絡する.

第 8 例: 検索例 No. 5 (Fig. 8 中の 8 )

右側 Th 11，12 位と左側 Th 12 位間の 横位の連絡でその経過中に右側内臟神経と連 絡する

第 9 例: 検索例 No. 6 (Fig. 9 中の 9) 右側星状神経節より出た 2 本の横枝は連結 して1本となり左下方に向かい，椎体中央部
で反転し左上方へと向かい左側 Th 2 位と連絡する.

第 10 例: 検索例 No. 6 (Fig. 9 中の 10)

右側 Th 3 位と左側 Th 4 位間の横位の連絡であ る.

第 11 例：検索例 No. 6 (Fig. 9 中の 11)

左右の Th 6 位間の横位の連絡である.

第 12 例：検索例 No. 8 (Fig. 10 中の 12)

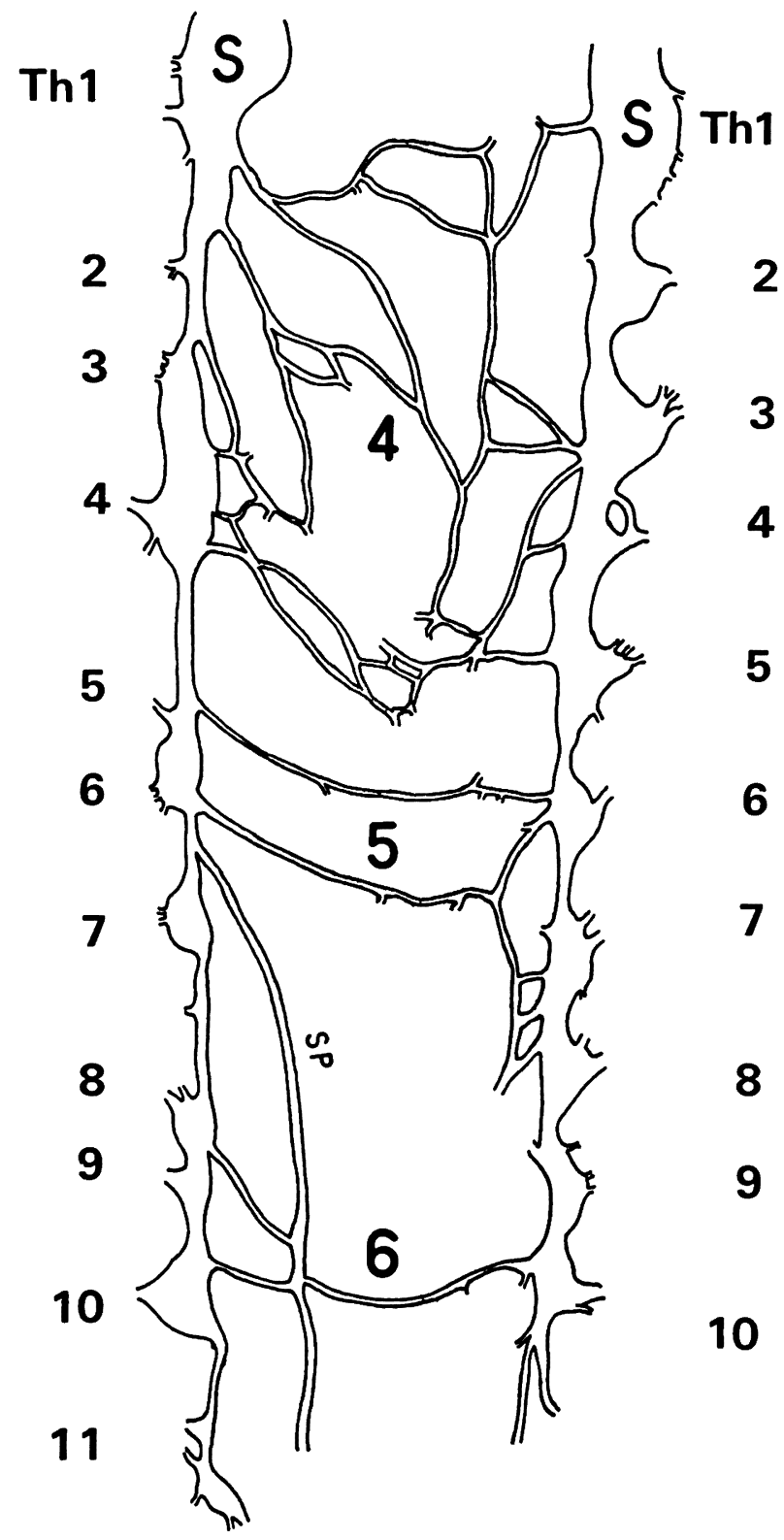

Fig. 6 Anastomosis of case No. 2 


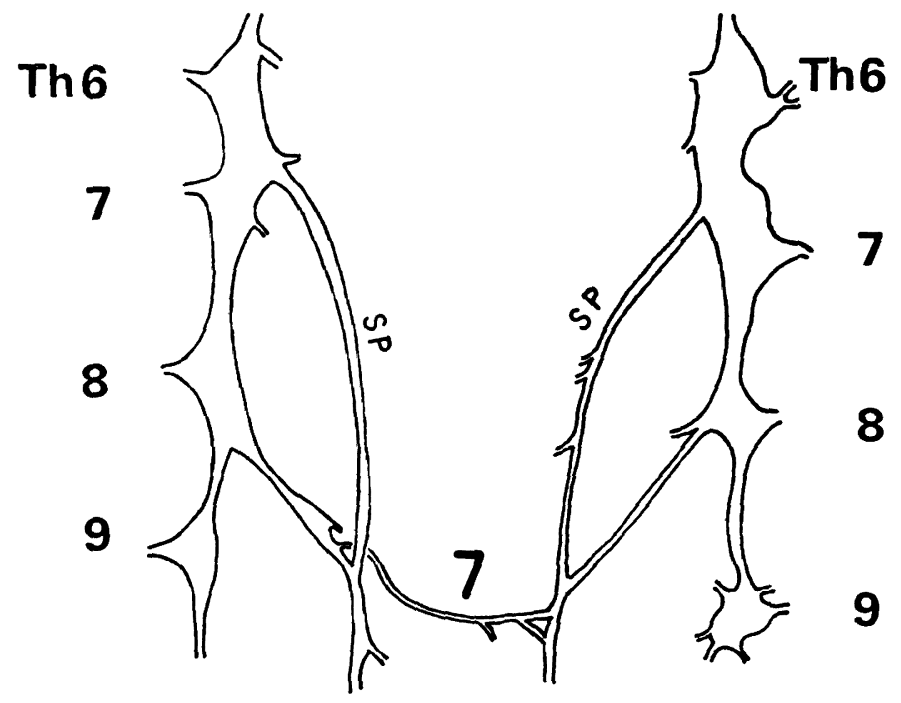

Fig. 7 Anastomosis of case No. 3

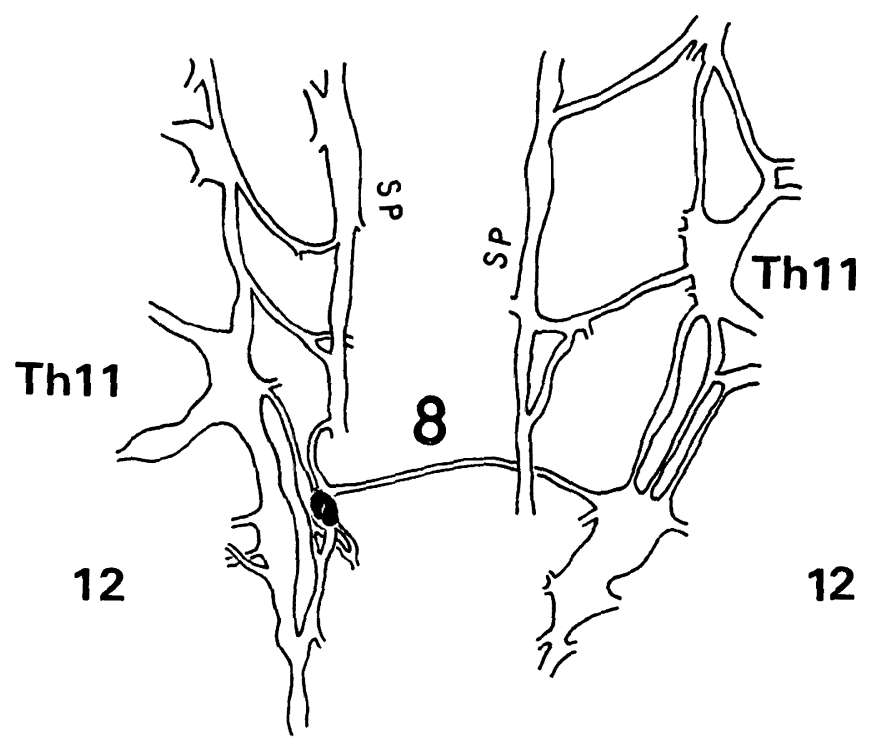

Fig. 8 Anastomosis of case No. 5

右 Th 5 位より出た 3 本の横枝は合して 1 本となり 椎体中央部でほぼ垂直に下方へ走り, 第 8 胸椎前面で 左方へと向かい，3本に分枝して左側 Th 6 および Th 7 位と連絡する.

第 13 例: 検索例 No. 9 (Fig. 11 中の 13)

右側 Th 5 位より出た横枝は左下方へと向かい第 6 胸椎中央部で左上方へと反転し，2本に分枝して左側 Th 5 位と連絡する.

第 14 例: 検索例 No. 10 (Fig. 12 中の 14)
右側 Th 3 位から Th 8 位の広範囲より出た 15 本の横枝は複雑に結合して叢を形成し，左下方へと向 かい椎体中央部をやや斜走した後, 左へ横走して左側 Th 4 位から Th 8 位にわたって連絡する.

\section{7. 交通枝と答髄神経前枝との吻合について} 交感神経の交通枝は一般に同じレベルの䄃哊神経前 枝と連絡し，その数は 1 本から数本であるとされてい る ${ }^{12 \sim 21)}$. しかし脊髄神経と対応する同レベルの交感 


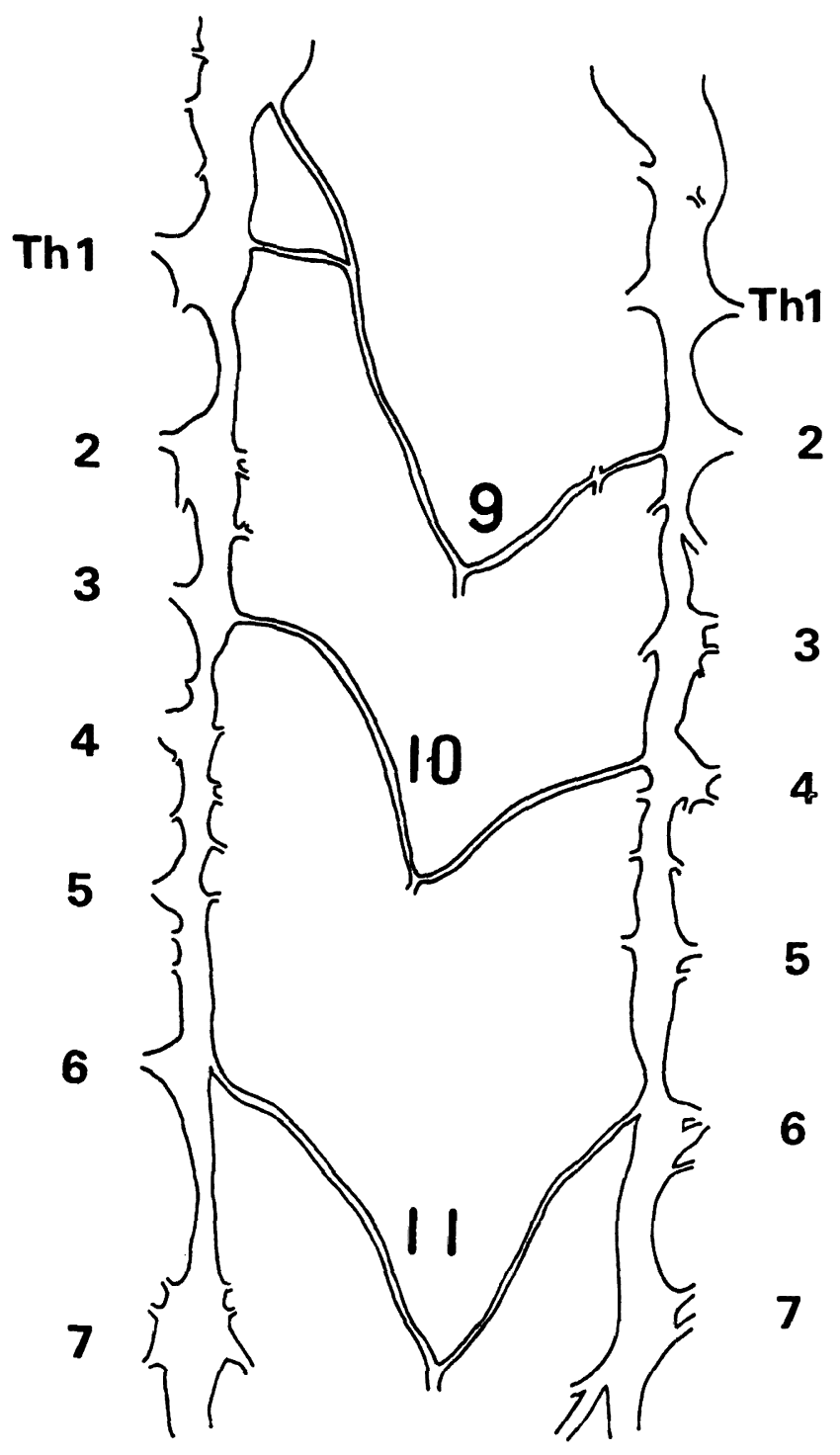

Fig. 9 Anastomosis of case No. 6

神経節が欠除している場合や，脊哊神経前枝が上下の 交感神経節や節間枝からの交通枝を受ける場合があ る. 春髄神経前枝に連絡する交通枝の数は Table 12, 13 のごとくとなった. すなわち春㖪神経前枝 1 本が 受ける交通枝の平均数は左右ともに約 3 本であった. 高位別では Th 2 位の脊咀神経前枝が受ける交通枝が 73 本で最多であった. 次に多かったのは Th 1 位の 70 本であったが, 交通枝の数は下位に行くに従って減 少する傾向がみられた. Table 13 は, 脊跶神経前 枝が上下のレベルの交感神経節や節間枝と交通する状
態を示したものであるが右側 51 本, 左側 46 本, 合計 97 本が観察された。これら 97 本のうち節間枝と脊噵 神経前枝との交通枝は右側 11 本, 左側 11 本, 合計 22 本であったこれらの交通枝は春髄神経からみて1椎 体上下にずれた交感神経節や節間枝との結合であり， 2 椎体以上ずれた交感神経節や節間枝との結合はみら れなかった，最も多かったのはTh 2 位の脊㖪神経前 枝と星状神経節との交通枝で右側 9 本, 左側 10 本, 合計 19 本であった. 


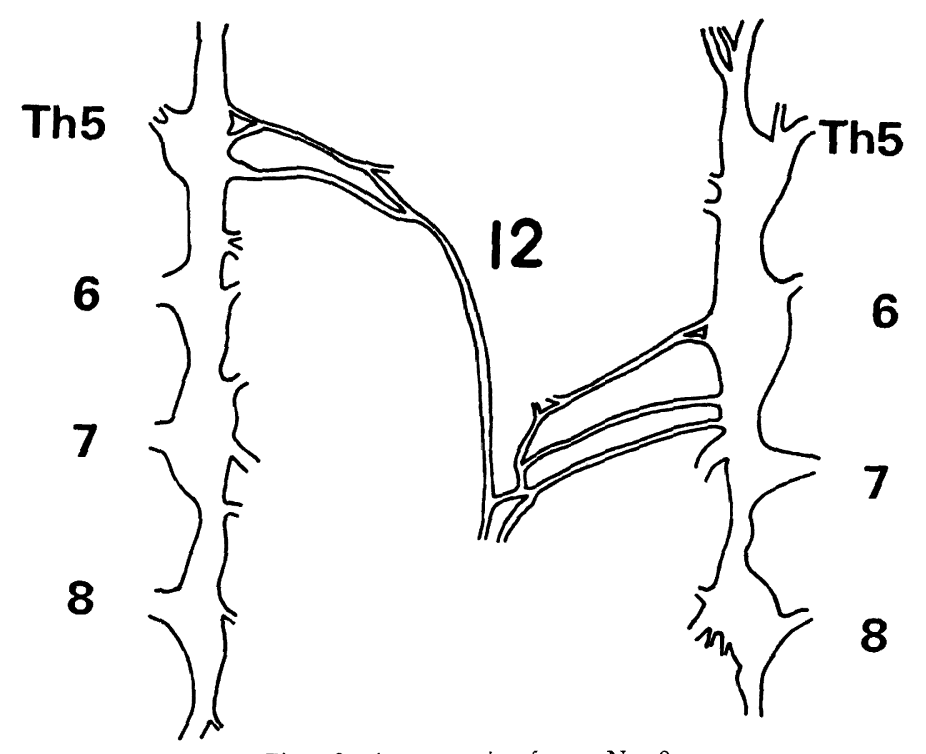

Fig. 10 Anastomosis of case No. 8

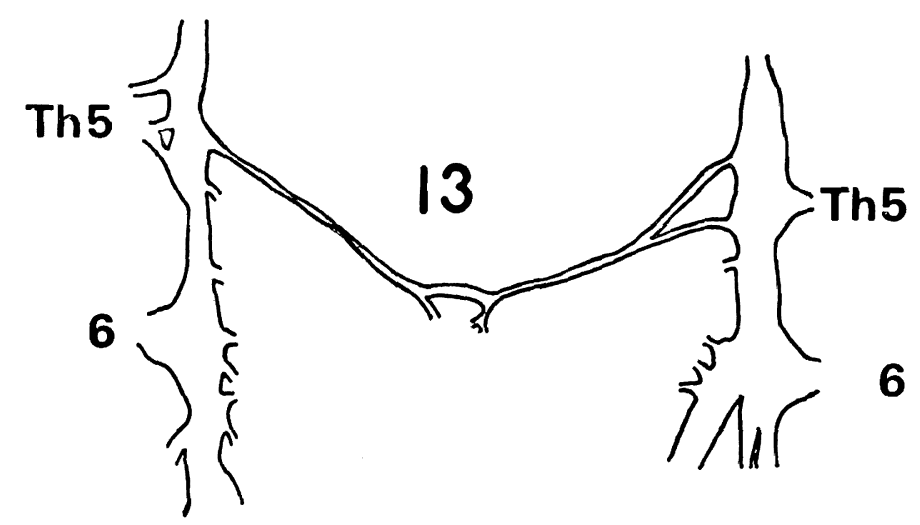

Fig. 11 Anastomosis of case No. 9

\section{8. 交通枝と脊髄神経後枝との吻合について}

交通枝と奉髄神経後枝との吻合については一般に成

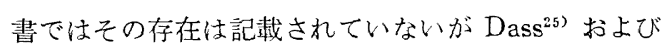
当教室の藤倉 ${ }^{26)}$, 迫田 ${ }^{6>}$ の報告がある. 今回の著者の 胸部における検索では 240 部位中 148 部位 (61.7\%) に交通枝が猆鹃神経後枝と結合していることが碓認さ れた（Table 14 および Plate 15). 高位についてみ ると上位ではやや少ない傾向がみられた. また, 左右 の差はあまりみられなかった. 最多出現例は検索例 No. 9 の 24 部位中 23 部位, 最少出現例は検索例 No. 1 の 24 部位中 1 部位と個体差が大きかった.

9. 交通枝と背髄神経硬膜枝との吻合について
今回の著者の胸部における検索では交通枝から分岐 した微細な小枝と脊髄神経硬膜枝とが結合している状 態が観察され, Table 15 に示すごとく 240 部位中 51 部位 $(21.3 \%)$ に確認された.

10. 副神経節 (ganglia intermedia) について (Plate 12, Photo 6)

交通枝の経過中にみられる肥厚部すなわち副神経節 (ganglia intermedia) は今回の著者の胸部における検 索では 4 個観察された. 第 1 例は検索例 No. 2 (Plate 2 ) で左側 Th 12 位, 第 2 例は検索例 No. 3 (Plate 3) で左側 Th 12 位, 第 3 例は検索例 No. 5 (Plate 5) で右側 Th 12 位, 第 4 例は検索例 No. 9 


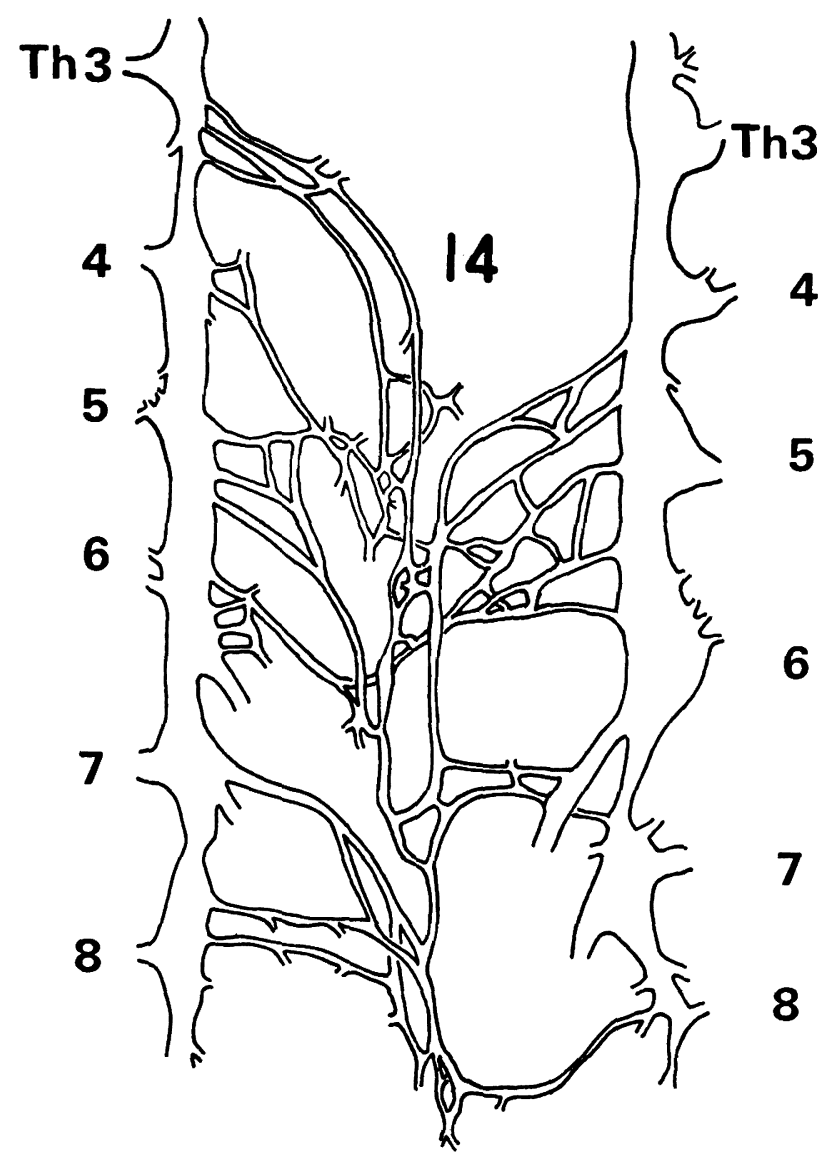

Fig. 12 Anastomosis of case No. 10

Table 12 Number of rami communicantes to a ramus ventralis of ten fetuses

\begin{tabular}{cccc}
\hline Level $(\mathrm{Th})$ & $\mathrm{R}$ & $\mathrm{L}$ & Total \\
\hline 1 & 33 & 37 & 70 \\
2 & 35 & 38 & 73 \\
3 & 34 & 31 & 65 \\
4 & 30 & 32 & 62 \\
5 & 30 & 30 & 60 \\
6 & 31 & 29 & 60 \\
7 & 29 & 31 & 60 \\
8 & 27 & 27 & 54 \\
9 & 30 & 26 & 56 \\
10 & 25 & 28 & 53 \\
11 & 31 & 26 & 57 \\
12 & 23 & 25 & 48 \\
\hline Total & 358 & 360 & 718 \\
\hline Average & 2.98 & 3.00 & \\
\hline
\end{tabular}

(Plate 9) で右側 Th 11 位であった. これを迫田 ${ }^{6)}$
の分類に従うと第 1〜3 例はいずれも Type B，第 4 例は Type C であった. ちなみに Type B は副 神経節が完全に交通枝の経過中に存在するものであ り, Type C は副神経節が脊髄神経に密接するもので ある.

\section{考 察}

当教室の迫田 ${ }^{6)}$ は, 本邦人胎児死体 10 体を研究材 料として腰部交感神経幹および幹神経節の形態学的特 徵について検索し腰痛との関連について臨床解剖学的 検討を加え報告した.今回著者はその一環として胸部 交感神経幹と幹神経節について検索した。

（i）胸部交感神経節の出現数の調査で胸部交感神経 節の上界については, 今回の検索では 10 体の両側に おいて 星状神経節を 観察しえたのでこれを上界とし 
$-76-(442)$

Table 13 Number of rami communicantes from different level of sympathetic trunk to a ramus ventralis

\begin{tabular}{cccccc}
\hline $\begin{array}{l}\text { level of } \\
\text { sympathetic } \\
\text { trunk } \\
(\mathrm{Th})\end{array}$ & $\begin{array}{l}\text { Level of } \\
\text { ramus } \\
\text { ventralis } \\
(\mathrm{Th})\end{array}$ & $\mathrm{R}$ & $\mathrm{L}$ & Total \\
\hline 1 & $\rightarrow$ & 2 & 9 & $10(1)$ & $19(1)$ \\
2 & $\rightarrow$ & 3 & 8 & $5(1)$ & $13(1)$ \\
3 & $\rightarrow$ & 4 & $4(2)$ & 2 & $6(2)$ \\
4 & $\rightarrow$ & 5 & $3(1)$ & $3(1)$ & $6(2)$ \\
5 & $\rightarrow$ & 6 & 2 & 1 & 3 \\
6 & $\rightarrow$ & 7 & $2(1)$ & 2 & $4(1)$ \\
7 & $\rightarrow$ & 8 & $1(1)$ & 0 & $1(1)$ \\
8 & $\rightarrow$ & 9 & 0 & 0 & 0 \\
9 & $\rightarrow$ & 10 & $3(1)$ & $5(2)$ & $8(3)$ \\
10 & $\rightarrow$ & 11 & $7(1)$ & $4(2)$ & $11(3)$ \\
11 & $\rightarrow$ & 12 & 4 & 0 & 4 \\
6 & $\rightarrow$ & 5 & $1(1)$ & 0 & $1(1)$ \\
12 & $\rightarrow$ & 11 & $4(1)$ & $10(3)$ & $14(4)$ \\
$\mathrm{L1}$ & $\rightarrow$ & 12 & $3(2)$ & $4(1)$ & $7(3)$ \\
\hline Total & & & $51(11)$ & $46(11)$ & $97(22)$ \\
\hline
\end{tabular}

$\rightarrow=$ Direction

( ) $=$ Rami communicantes from rami interganglionares

た.下界については第 12 胸部脊髅神経と交通枝を持 つ交感神経節, すなわち第 12 胸部交感神経節である ことについては一致しているが7 22)，その同定につい ては横隔膜 (松井 ${ }^{7)}$, 前田 ${ }^{10,11)}$ ), 椎体 $\left(\right.$ Krause $\left.^{8)}\right)$, 交通枝を特に重要視する (松島 ${ }^{8)}, \mathrm{Pick}^{22)}$ ) などを基準 とする報告がある. 松島 ${ }^{8)}$ は第 12 胸部交感神経節の 位置が不定であること, また Pick ${ }^{22)}$ は, 癒合, 分裂 によりその存在が明らかでないことなどにより同定が 至難であることを強調している. 実際に松島到はその 観察所見において第 12 胸部交感神経節はたびたび腹 腔内あるいは横隔膜起始部の内に存在したと報告して

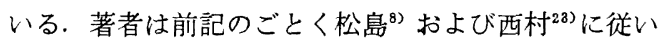
第 12 胸部脊随神経と神経節との交通枝の走行状態お よび, 神経節と椎体との位置関係（第 11 胸椎から第 1 腰椎上に存在する神経節）により第 12 胸部交感神 経節を同定した. また, 同時に第 11 胸部交感神経節 および第 1 腰部交感神経節も確認した, 胸部交感神経 節を観察するにあたり松井 ${ }^{7)}$, 松島 ${ }^{8)}$ は合併している 神経節はこれを 2 個と数え, 分割している神経節はこ れを合わせて 1 個と数えて胸部交感神経節の出現数を 松井 ${ }^{7)}$ は 11.2 個, 松島 ${ }^{8)}$ は 11 12 個 (86\% は 12 個）と報告している. ちなみに他の研究者 ${ }^{9 \sim 11)}$ の報 告も胸部交感神経節の出現数は 10〜12 個であった. 前田ら ${ }^{11)}$ は胎児 11.26 個, 成人 11.25 個と報告して
いるが癄合型交感神経節および接触型交感神経節（節 間枝が存在するが極めて短く，2 ないし 3 個の神経節 が相接する状態にあるもの）をそれぞれ分離して算定 した.また，胎児と成人の癒合型交感神経節および接 触型交感神経節の出現率の比較を行い胎㫛 $8.87 \%$, 成 人 $3.23 \%$ にこれらの神経節が出現していたとも報告 している. すなわちこのように瘾合型および接触型交 感神経節が胎児に多く出現するのは, 神経節が個体の 成長に従って分離していく事象を示すものであると推 察している. 今回の著者の検索では, 癒合型および接 触型交感神経節の接合部にも組織標本を作製してみる と神経細胞が存在していることが確認されたのでこれ らの神経節をすべて 1 個として算定した. その結果, 検体 10 体における胸部交感神経節の総数は 206 個 で平均は 10.3 個 (片側) となった.

（ii）星状神経節については 10 検体 20 部位で 20 個すなわち 100\% にその出現が観察された.ちなみ に Atumi ${ }^{9)}$ は星状神経節の出現率を $84 \%$, 前田ら ${ }^{11}$ は胎児で $88.9 \%$ ，成人で $81.3 \%$ であったと報告して いる. なお検索例 No. 1 の左側 1 部位のみで星状神経 節は第 2 胸部神経節と癒合しておりこれは $5 \%$ の出現 率である. Atumi ${ }^{9)}$ は星状神経節 42 個中 2 個が第 2 胸部神経節をも澳合していたと報告しており，出現率 は 4.76\% で著者の出現率とほぼ一致する. 形状につ いては Atumi ${ }^{92}$, 前田ら ${ }^{10,11)}$ は星状神経節を南瓜型, 不正長方形型, 珠数型および卵円形型と 4 型に分類し ているが，著者の検索では南瓜型と卵円形型との区別 がつきにくくこれらを合わせて Type I とし 3 型に分 類した. その結果, 最も多かったのは Type I の 9 個 (45\%) で, 次いで Type IIIの6 個 $(30 \%)$, Type II の 5 個 (25\%) であった. Atumi ${ }^{9)}$, 前田ら ${ }^{10,11)}$ の報 告では南瓜型が過半数を占め（それぞれ $76.19 \%$ お よび 63.3\%), 不正長方形型, 珠数型, 卵円形型がこれ に次いでいた. 大きさについては長径 $\times$ 短径を測定し たところ最大は Type III の $9.25 \times 2.29 \mathrm{~mm}$ で最小は Type IIの $4.40 \times 1.38 \mathrm{~mm}$ であった. 平均値でみる と Type IIIが最も大きく Type I , Type II がこれに 次いでいた. 星状神経節全体の平均は $5.39 \times 2.09 \mathrm{~mm}$ であった.

（iii）第 2 胸部交感神経節以下の神経節をその形態 により非癔合型交感神経節と癒合型交感神経節に分類 した. 非疮合型交感神経節の同定については，隣接す る神経節間に節間枝が存在し, かつ同じレベルの䄃蹎 神経と交通枝をもっている神経節を非疮合型交感神経 
Table 14 Rami communicantes to ramus dorsalis

\begin{tabular}{|c|c|c|c|c|c|c|c|c|c|c|c|c|c|c|}
\hline \multicolumn{2}{|c|}{$\mathrm{Case}^{\mathrm{Th}}$} & 1 & 2 & 3 & 4 & 5 & 6 & 7 & 8 & 9 & 10 & 11 & 12 & Total \\
\hline \multirow{2}{*}{1} & $\mathrm{R}$ & - & - & - & 0 & - & - & - & - & - & - & - & - & 1 \\
\hline & $\mathrm{L}$ & - & - & - & - & - & - & - & - & - & - & - & - & 0 \\
\hline \multirow[t]{2}{*}{2} & $\mathrm{R}$ & 0 & 0 & 0 & 0 & 0 & 0 & 0 & - & 0 & 0 & 0 & - & 10 \\
\hline & $\mathrm{L}$ & - & 0 & 0 & 0 & 0 & 0 & 0 & 0 & 0 & 0 & 0 & - & 10 \\
\hline \multirow{2}{*}{3} & $\mathrm{R}$ & 0 & 0 & 0 & 0 & 0 & 0 & 0 & 0 & 0 & 0 & 0 & 0 & 12 \\
\hline & $\mathrm{L}$ & 0 & - & - & 0 & 0 & 0 & 0 & 0 & 0 & 0 & 0 & 0 & 10 \\
\hline \multirow{2}{*}{4} & $\mathrm{R}$ & - & $\bigcirc$ & $\bigcirc$ & 0 & 0 & 0 & 0 & 0 & 0 & 0 & 0 & 0 & 11 \\
\hline & $\mathrm{L}$ & - & 0 & 0 & - & 0 & 0 & 0 & 0 & 0 & - & - & 0 & 8 \\
\hline \multirow[t]{2}{*}{5} & $\mathrm{R}$ & - & - & - & 0 & - & 0 & - & 0 & - & - & - & - & 3 \\
\hline & $\mathrm{L}$ & - & - & 0 & - & - & - & - & - & - & - & 0 & - & 2 \\
\hline \multirow{2}{*}{6} & $\mathrm{R}$ & - & - & - & - & 0 & - & 0 & 0 & 0 & 0 & 0 & 0 & 7 \\
\hline & $\mathrm{L}$ & 0 & 0 & 0 & 0 & 0 & 0 & 0 & 0 & 0 & 0 & 0 & 0 & 12 \\
\hline \multirow{2}{*}{7} & $\mathrm{R}$ & - & 0 & 0 & 0 & 0 & 0 & - & 0 & - & - & - & 0 & 7 \\
\hline & $\mathrm{L}$ & 0 & $\bigcirc$ & $\bigcirc$ & 0 & - & 0 & 0 & 0 & - & 0 & 0 & 0 & 10 \\
\hline \multirow{2}{*}{8} & $\mathrm{R}$ & 0 & - & 0 & - & - & - & - & - & - & - & 0 & 0 & 4 \\
\hline & L & - & - & - & - & - & 0 & - & 0 & 0 & 0 & 0 & 0 & 6 \\
\hline \multirow[t]{2}{*}{9} & $\mathrm{R}$ & 0 & 0 & 0 & 0 & 0 & 0 & 0 & 0 & 0 & 0 & 0 & - & 11 \\
\hline & $\mathrm{L}$ & 0 & 0 & 0 & 0 & 0 & 0 & 0 & 0 & 0 & 0 & 0 & 0 & 12 \\
\hline \multirow{2}{*}{10} & $\mathrm{R}$ & - & - & - & - & - & 0 & - & 0 & 0 & 0 & 0 & - & 5 \\
\hline & $\mathrm{L}$ & - & - & - & 0 & 0 & 0 & 0 & 0 & - & - & 0 & - & 6 \\
\hline Total & $\mathrm{R}$ & 4 & 5 & 6 & 7 & 6 & 7 & 5 & 7 & 6 & 6 & 7 & 5 & 71 \\
\hline Total & $\mathrm{L}$ & 4 & 5 & 6 & 6 & 6 & 8 & 7 & 8 & 6 & 6 & 8 & 7 & 77 \\
\hline \multicolumn{2}{|c|}{$\mathrm{R}+\mathrm{L}$} & 8 & 10 & 12 & 13 & 12 & 15 & 12 & 15 & 12 & 12 & 15 & 12 & 148 \\
\hline
\end{tabular}

節とした. 出現数は右側 76 個, 左側 77 個で合計 153 個であった. その出現状態を高位別にみると Th 4, Th 5 位および Th 11, Th 12 位で減少していた. これはこの部位で疮合型交感神経節が多いことを示 し，また，この部位より内臟神経が派出することにも 関連していると思われる. 非癒合型交感神経節の形状 については迫田の)の分類に従い 5 型に分類した. 最も 多かったのは Type II の三角形型で 77 個(50.3\%), 次いで Type IV の星型 27 個(17.7\%), Type I の長 楕円形型 22 個 (14.4\%), Type IIIの四辺形型 19 個 (12.4\%), Type V の不規則型 8 個 (5.2\%) であっ た. 各型の高位別出現数をみると Type I， II， III 上位から下位にまで分布しているが，複雑な形の Type IV, Vが中位から下位にかけて多く出現するの は内臟神経との連絡や, 胸部交感神経幹が椎体側面に 移動することなどの影響が考えられる．大きさについ ては長径×短径として表したところ平均は $2.47 \times$
$1.59 \mathrm{~mm}$ であった. 最大は Type I の $4.88 \times 1.94$ $\mathrm{mm}$, 最小は Type II $1.10 \times 0.53 \mathrm{~mm}$ であった. また，右側より左側のほうが大きく，下位に行くに従 い小さくなる傾向がみられた。

(iv) 痹合型交感神経節 (第 2 胸部交感神経節以下) については，節間枝が消失して上下の神経節が直接連 絡している場合や，1個の神経節から上下にわたる脊 娟有神経に交通枝を出し，かつ同じレベルに他の神経節 が存在しない場合にこれらを瘾合型交感神経節とし 4 型に分類した. 瘱合型交感神経節の出現数は右側 18 個，左側 15 個で合計 33 個であった. 寸なわち $16.0 \%$ の出現率となるが, これは Atumi ${ }^{9)}$ の 3.75\%, 前田 $5^{10,11)}$ の胎児 $8.87 \%$, 成人 $3.25 \%$ の瘾合型交感神 経節の出現率と比べかなり多い出現率であった. 形状 に上る分類では最も多かったのは Type II の 14 個 (42.4\%) で最も少なかったのは Type III の 3 個 (9.1 \%) であった. これを高位別にみると Th $3 \sim 5$ 位お 
Table 15 Rami communicantes to ramus meningeus

\begin{tabular}{|c|c|c|c|c|c|c|c|c|c|c|c|c|c|c|}
\hline \multicolumn{2}{|c|}{ Case } & 1 & 2 & 3 & 4 & 5 & 6 & 7 & 8 & 9 & 10 & 11 & 12 & Total \\
\hline \multirow{2}{*}{1} & $\mathrm{R}$ & - & - & - & - & - & - & - & - & - & - & - & - & 0 \\
\hline & $\mathrm{L}$ & - & - & - & - & - & - & - & - & - & - & - & - & 0 \\
\hline \multirow{2}{*}{2} & $\mathrm{R}$ & - & - & - & 0 & - & 0 & - & - & 0 & 0 & - & - & 4 \\
\hline & $\mathrm{L}$ & - & 0 & - & 0 & 0 & - & 0 & 0 & 0 & - & 0 & 0 & 8 \\
\hline \multirow{2}{*}{3} & $\mathrm{R}$ & - & - & - & 0 & 0 & 0 & - & - & - & 0 & 0 & - & 5 \\
\hline & $\mathrm{L}$ & - & - & - & - & - & 0 & - & 0 & - & - & 0 & $\mathrm{O}$ & 4 \\
\hline \multirow{2}{*}{4} & $\mathrm{R}$ & - & 0 & - & - & - & - & - & - & - & - & 0 & - & 2 \\
\hline & $\mathrm{L}$ & - & - & 0 & - & - & 0 & 0 & 0 & - & - & - & - & 4 \\
\hline \multirow{2}{*}{5} & $\mathrm{R}$ & - & - & - & - & - & - & - & - & - & - & - & - & 0 \\
\hline & $\mathrm{L}$ & - & - & - & - & - & - & - & - & - & - & - & - & 0 \\
\hline \multirow{2}{*}{6} & $\mathrm{R}$ & - & - & - & - & - & - & - & - & - & - & - & - & 0 \\
\hline & $\mathrm{L}$ & - & - & - & - & - & - & - & - & - & - & - & - & 0 \\
\hline \multirow{2}{*}{7} & $\mathrm{R}$ & - & - & - & - & 0 & - & - & - & - & - & - & 0 & 2 \\
\hline & $\mathrm{L}$ & - & - & - & - & 0 & 0 & 0 & - & - & 0 & - & 0 & 5 \\
\hline \multirow[t]{2}{*}{8} & $\mathrm{R}$ & - & - & - & - & - & 0 & - & - & - & - & - & - & 1 \\
\hline & $\mathrm{L}$ & - & - & - & - & - & 0 & - & - & $\bigcirc$ & 0 & 0 & 0 & 5 \\
\hline \multirow{2}{*}{9} & $\mathrm{R}$ & - & - & - & - & - & 0 & 0 & - & 0 & - & - & - & 3 \\
\hline & $\mathrm{L}$ & 一 & - & 0 & 0 & 0 & 0 & 0 & 0 & - & 0 & 0 & - & 8 \\
\hline \multirow{2}{*}{10} & $\mathrm{R}$ & - & - & - & - & - & - & - & - & - & - & - & - & 0 \\
\hline & $\mathrm{L}$ & - & - & - & - & - & - & - & - & - & - & - & - & 0 \\
\hline Total & $\mathrm{R}$ & 0 & 1 & 0 & 2 & 2 & 4 & 2 & 0 & 2 & 2 & 2 & 1 & 18 \\
\hline Total & $\mathrm{L}$ & 0 & 1 & 2 & 2 & 3 & 5 & 3 & 4 & 2 & 3 & 4 & 4 & 33 \\
\hline \multicolumn{2}{|c|}{$R+L$} & 0 & 2 & 2 & 4 & 5 & 9 & 5 & 4 & 4 & 5 & 6 & 5 & 51 \\
\hline
\end{tabular}

よび Th 10〜12 位に多く出現する傾向がみられた.

（v）両側交感神経幹間の吻合枝（横枝）は脊柱前 面に接して走行しているため, 脊柱から直接任迫, 毫 引等の刺激を受けやすく背部痛の一因となりらるもの であろう。 その存在について腰部においては松島 ${ }^{8)}$, Webber $^{24)}$, 迫田 ${ }^{6)}$ の報告があるが胸部においては報 告がみられない.今回の著者の胸部における検索では, 10 検体中 8 体 14 部位において両側交感神経幹間の吻 合枝を確認しえたのでその全例について図説した (Fig. 5 12).

（vi）交通枝と沶髄神経前枝との吻合は全部位にお いて観察され 1 部位あたりの交通枝の数住両側とも平 均 3 本であった. 高位別にみると下位に行くに従って 交通枝の数が減少していた. また, 脊髄神経前枝が上 下のレベルの神経節や節間枝と交通している部位が観 察された.これらの交通枝は脊髄神経前枝からみて1 椎体上下にずれた神経節および節間枝との交通であり
2 椎体以上，上下にずれた交通はみられなかった。

（vii） 交通枝と脊髄神経後枝との吻合については従 来解剖成書にその記载はなくわずかに Dass ${ }^{25}$ の報告 があるのみであった. Dass は成人死体 2.5 体の頭部 から腰仙部までの検索を行った結果 33 部位 (21.3\%) において交通枝と脊髄神経後枝との吻合を確認しこ れを 3 型に分類した. 当教室の藤倉 ${ }^{26)}$ は, 成人死体 4 体の腰部 40 部位を検索しその $50 \%$ に交通枝と脊 髄神経後枝との連結を確認し報告した. また, 当教室 の迫田 ${ }^{6)}$ は, 胎児死体 10 体の腰部 100 部位を検索 しその $34 \%$ に交通枝と脊髄神経後枝との連結を確認 したと報告している.今回の著者の胸部における検索 では, 240 部位中 148 部位 $(61.7 \%)$ に交通枝と春髄 神経後枝との連結を確認しえた（Plate 15).

交通枝と脊髄神経後枝との連結の出現は右側 71 部 位, 左側 77 部位で左右の差はあまりないが最多出現 例は検索例 No. 9 の 24 部位中 23 部位, 最少出現 
例は検索例 No. 1 の 24 部位中 1 部位と個体差が大 きかった. Dass ${ }^{25)}$ の検索で確認された 155 部位中 33 部位の交通枝と脊喵神経後枝との連結の5ち 24 部 位 $72.7 \%$ ) は Th 1 11 位の間の胸部に確認されて いる.

（viii）交通枝と春䯑道神経硬膜枝との吻合については 久良木 ${ }^{27)}$ が腰部における脊髄神経硬膜枝の構成につい て検索し，交通枝も構成因子となっていると報告して いる. 今回の著者の胸部における検索では, 240 部位 中 51 部位 $(21.3 \%)$ に交通枝と宵髄神経硬膜枝との 連結を確認しえた。

（ix） 副神経節は 4 個が確認された。いずれも Th 11位および Th 12 位の脊喣神経前枝と連結している 交通枝の経過上にあり迫田 ${ }^{6)}$ の分類に従うと Type B が 3 個, Type C が 1 個であった. ちなみに副神経節 について先人の報告は松井 ${ }^{77}$, 岩間 ${ }^{28)}$, 松島 ${ }^{8)}$, 藤倉 ${ }^{26)}$, Feneis $^{29)}$ および上記迫田 ${ }^{6)}$ らのわずかな観察記録が みられるのみで胸部について言及しているのは松井 の1例の記載のみであった.

\section{結 論}

日本医科大学第 2 解剖学教室所蔵の胎児死体 $(5 \sim 6$ 力月齢) 10 体を用い，両側胸部交感神経幹の走行およ び吻合枝, 交感神経節の形態, 交通枝の状態について 肉眼的観察を行い下記のごとき所見を得た.

1) 胸部交感神経幹は, 頚部から胸部への移行部で 方向を背方にとり，第 1 肋骨頭に達し，この部位で全 例両側ともに第 1 胸部交感神経節は下䅡神経節と合し て星状神経節（頝胸神経節）を形成していた.

2) 胸部交感神経節の総数（星状神経節をも第 1 胸 部交感神経節として算定）は 206 個であった. 右側 104 個, 左側 102 個で片側の平均は 10.3 個であっ た.

3）星状神経節は形状により 3 型に分類しえた．星 状神経節の大きさ (長径 $\times$ 短径) の平均は $5.39 \times 2.09$ $\mathrm{mm}$ であった.

4）第 2 位以下のレベルの胸部交感神経節は総数 186 個観察され，またその形状により非瘾合型交感神 経節と瘾合型交感神経節とに分類した。非痹合型交感 神経節の出現数は 153 個でその出現率は $74.3 \%$ であ った。 また, 非癒合型交感神経節は形状により 5 型に 分類しえた．非癒合型交感神経節の大きさ（長径 $\times$ 短 径）の平均は $2.47 \times 1.59 \mathrm{~mm}$ であった. 疮合型交感 神経節の出現数は 33 個でその出現率は $16.0 \%$ であ
った。また，癒合型交感神経節は形状により4 型に分 類しえた．㾑合型交感神経節の大きさ（長径 $\times$ 短径） の平均は $4.89 \times 1.71 \mathrm{~mm}$ であった.

5）両側交感神経幹間を結合する横位の吻合は，10 検体中 8 体の 14 部位に観察された. 各々の所見につ いては図説した.

6）胸部交感神経幹の交通枝と春㖪神経前枝との吻 合は全部位において観察され，その交通枝の総数は 718 本であった. 交通枝の 1 部位あたりの平均数は左 右とも 3 本であった. また，交通枝の数は下位に行く に従い減少していた.

7) 胸部交感神経幹の交通枝と春髄神経後枝との吻 合は, 10 検体 240 部位中 148 部位 (61.7\%) に確認 された，その代表的所見については図説した.

8）胸部交感神経幹の交通枝と脊䯣神経硬膜枝との 吻合は, 10 検体 240 部位中 51 部位 (21.3\%) に確 認された.

9）副神経節（ganglia intermedia）は全例中に 4 個観察された。

稿を終わるに臨み，終始ご指導ならびにご鞭撻を賜った日 本医科大学第 2 解剖学教室の田沼久美子助教授に深甚なる謝 意を捧げます。またご協力戴いた第2解剖学教室員各位に感 謝の意を表します。

な㧍，本論文の要旨は第 68 回日本解剖学会関東地方会 （1984）に扔いて発表した。

\section{文 献}

1) Nathan, H. : Compression of the sympathetic trunk by osteophytes of the vertebral column in the abdomen; An anatomical study with pathological and clinical considerations. Surgery, 63, 609 625, 1968.

2）福山右門 : 交感神経の解剖上外科への応用. 医学のあ ゆみ, 44, 241 247, 1963.

3）福山右門，伊藤金得：交感神経幹に出入する求心性神 経線維について。解剖誌，41，199，1966.

4）福山右門：自律神経系のなかの求心性神経線維. 解剖 誌, 42, 11 12, 1967.

5）福山右門：福山右門教授研究業績目録. 千葉大学医学 部第 1 解剖学教室, 1975.

6）迫田哲司：ヒ卜胎児腰部交感神経幹上幹神経節の形態 学的検索. 日医大誌, 50, 681 692, 1983.

7) Matsui, Y. : Beitraege zur Kenntnis der Anatomie des sympathischen Nervensystems. Acta scholae medic, univers. Kioto, 8, 1 42, 1925.

8）松島茂：第 12 胸部交感神経節に就て。満州医誌，10, $291 \sim 314,1929$.

9) Atumi, H. : Über den Verlauf, insbesondere die Spaltung und die sogennante Unterbrechung des Brustgrenzstranges bei Japanern. Redaktion der Okajimas Folia. Anat. Jap., 22, 511 549, 1944. 
$-80-(446)$

10）前田奏行, 前原東作, 松元誠一：九州日本人（成人） の胸部交感神経節について．鹿児島医誌，33，1855～ 1857,1960

11）前田実行, 松山静雄, 丸田実行 : 九州日本人（胎児） の胸部交感神経節について. 庇児島医誌，34，642～ $644,1961$.

12）金子丑之助：日本人体解剖学: 3 . 篮 15 版, p. $632 \sim 658$ 南山堂, 東京, 1973.

13) 平沢與, 岡本道雄: 解剖学 2. p. 420 441, 金湶住版, 東京, 1965 .

14) Ranson, S.W. : Anatomy of the Nervous System. 9th edition, p. $135 \sim 150$, W.B. Saunders, Philadelphia \& London, 1953.

15) Mitchell, G.A.G. : Anatomy of the Nervous System. p. $201 \sim 256$, E. \& S. Livingstone, Edinburgh and London, 1953.

16) Kopsch, F. : Lehrbuch und Atlas der Anatomie des Menschen. Vol. 3, p. 318 335, Georg Thieme, Leipzig, 1953.

17) Braus, H. : Anatomie des Menschen. Vol. 3, 2nd edition, p. $350 \sim 365$, Springer Verlag, Berlin, 1960.

18) Spalteholz, W. : Handatlas der Anatomie des Menschen. Zweiter Teil, p. 414 424, Schltema \& Holkema N.V., Amusterdam, 1961.

19) Hollinshead, W.H. : Anatomy for Surgeons. Vol. 2, 2 nd edition, p. 202 215, Harper \& Row, New York, 1971.

20) Goss, C.M.A.B. : Gray's Anatomy. 29th American edition, p. 1010 1036, Lea \& Febiger, Philadelphia, 1973.

21) Romanes, G.J. : Cunningham's Textbook of Anatomy. 12th edition, p. $810 \sim 821$, Oxford Univ. Press, Oxford, 1981.

22) Pick, J.: The identification of Sympathetic Segments. Ann. Surg., 145, p. 355 365, 1957.

23）西村貞男：坐骨神経根と交感神経交通枝との交通に関 する臨床的ならびに解剖学的研究. 日医大誌, 38, 21 $\sim 29,1971$.

24) Webber, R.H. : An analysis of the cross communications between the sympathetic trunks in the lumber region in man. Ann. Surg., 145, 365 370, 1957.

25) Dass, R. : Sympathetic components of the dorsal primary divisions of human spinal nerves. Anat. Rec., 113, p. 493 501, 1952.

26）藤倉国男：七卜腰部交感神経交通枝の形態学的検索; 腰部交感神経交通枝と㧝髅神経後枝との結合について。 日医大誌, 43，241 251，1976.

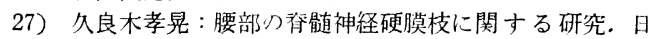
医大誌，40，143 152，1973.

28）岩間義夫 : 腹部交感神経交通枝に於ける副神経節につ いて. 日外宝, 3，1159～1169，1926。

29) Feneis, H. : Anatomischs Bildwörterbuch der inter- nationalen Nomenklatur, 3 Auf. p. 312, Georg Thieme Verlag, Stuttgart, 1972.

\section{Legends}

Plate 1 Drawing of the thoracic portion of the sympathetic trunks of case 1

Plate 2 Case 2

Plate 3 Case 3

Plate 4 Case 4

Plate 5 Case 5

Plate 6 Case 6

Plate 7 Case 7

Plate 8 Cese 8

Plate 9 Case 9

Plate 10 Case 10

Plate 11 15

Photo 1,2 Ventral aspects of the thoracic portions of the sympathetic trunks of case 9

Photo 3,4 Stellate ganglia

Photo 5 Cross communications between the right and the left sympathetic trunks in case 2

Photo 6 Ganglia intermedia on the ramus communicants in case 2

Photo $7 \sim 10$ Nonfusional form ganglia

Photo 11 14 Fusional form ganglia

Photo 15, 16 Rami communicantes to the dorsal ramus of the thoracic spinal nerve

Schemata $15^{\prime}, 16^{\prime}$ Schemata of photos 15 and 16 Ventral ramus of the thoracic spinal nerve in photo 15 and schema $15^{\prime}$ was turned over upward in photo 16 and schema $16^{\prime}$.

\section{Abbreviations}

AN : Anastomosis between the right and the left sympathetic trunks

GI : Ganglia intermedia

GS : Spinal ganglion

L : Lumber spinal nerve

$\mathrm{RC}$ : Ramus communicants to the thoracic spinal nerve

$\mathrm{RCD}$ : Ramus communicants to the dorsal ramus of the thoracic spinal nerve

$\mathrm{RCV}$ : Ramus communicants to the ventral ramus of the thoracic spinal nerve

$\mathrm{S}$ : Stellate ganglion

SP : Splanchnic nerve

$\Gamma$ : Sympathetic trunk

Th: Thoracic spinal nerve 


\section{Plate (1)}

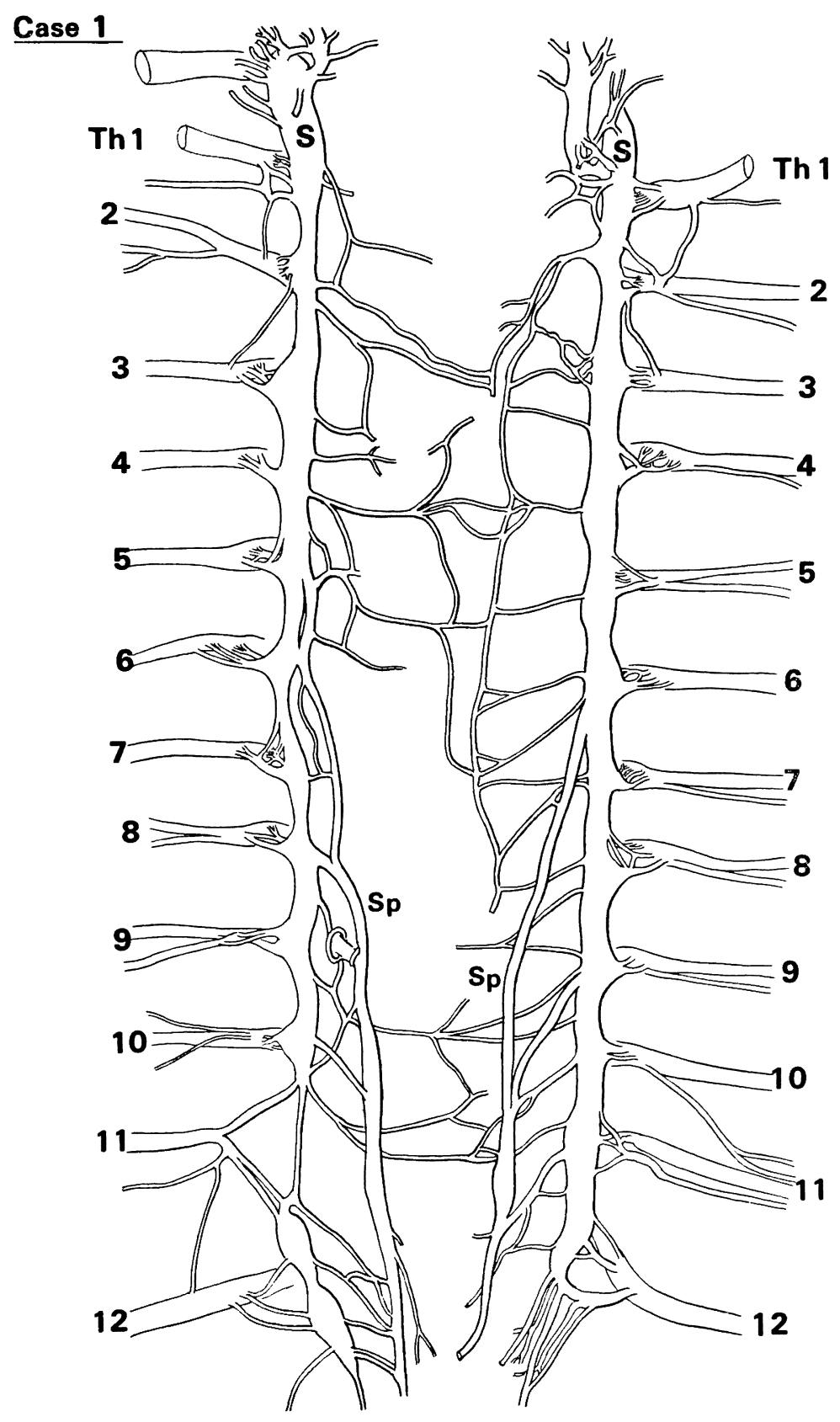




\section{Case 2}

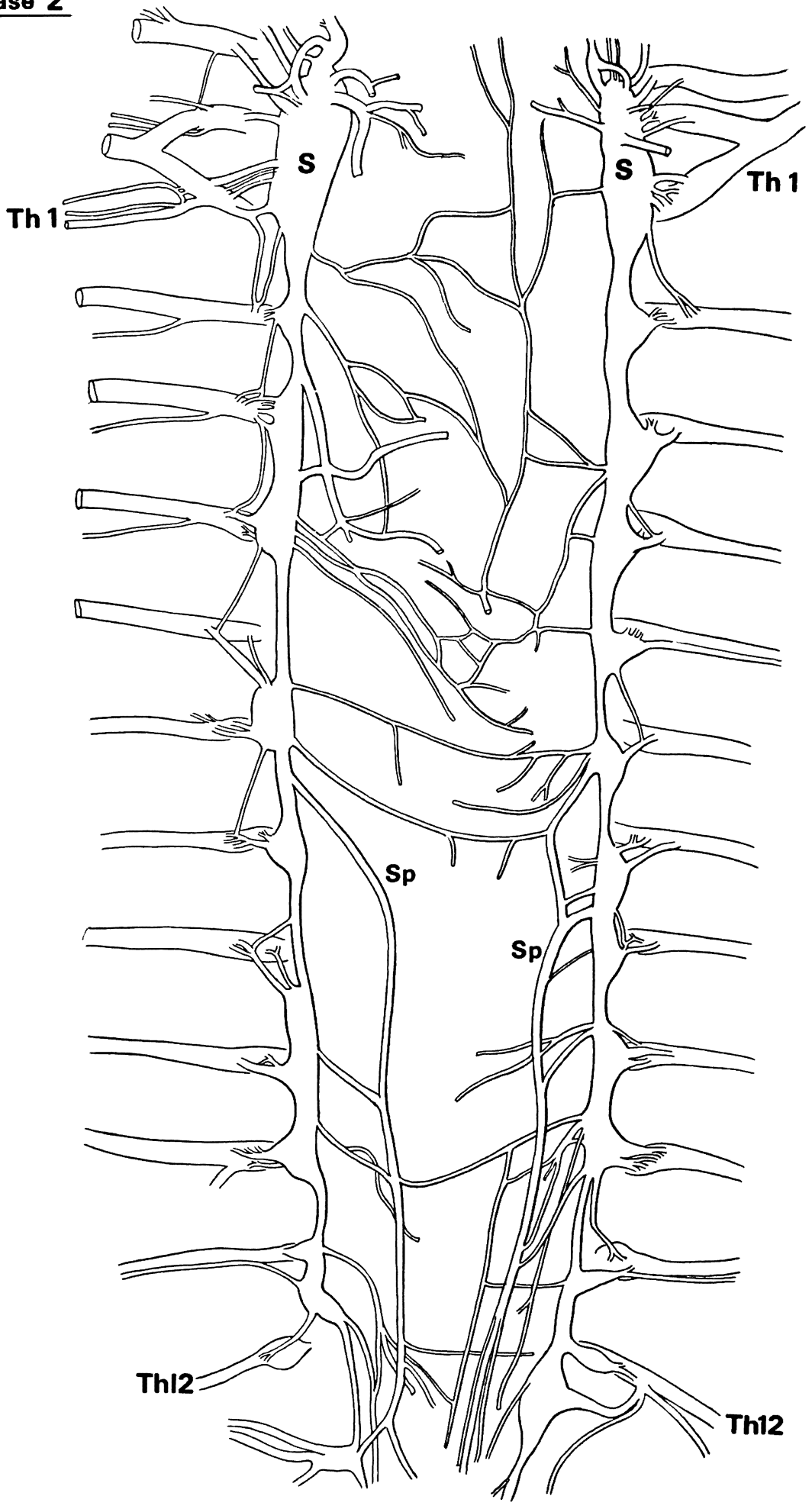




\section{Plate (3)}

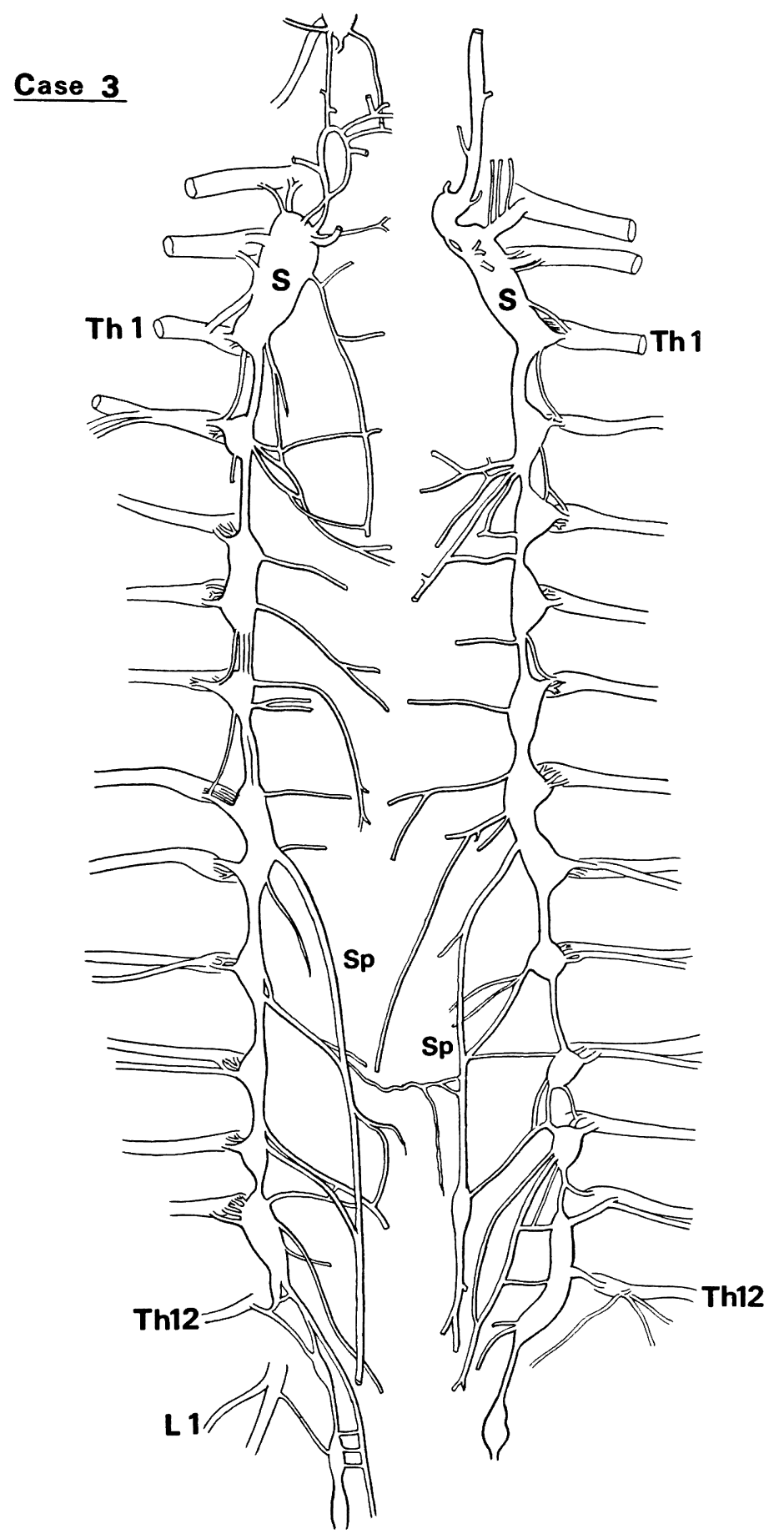




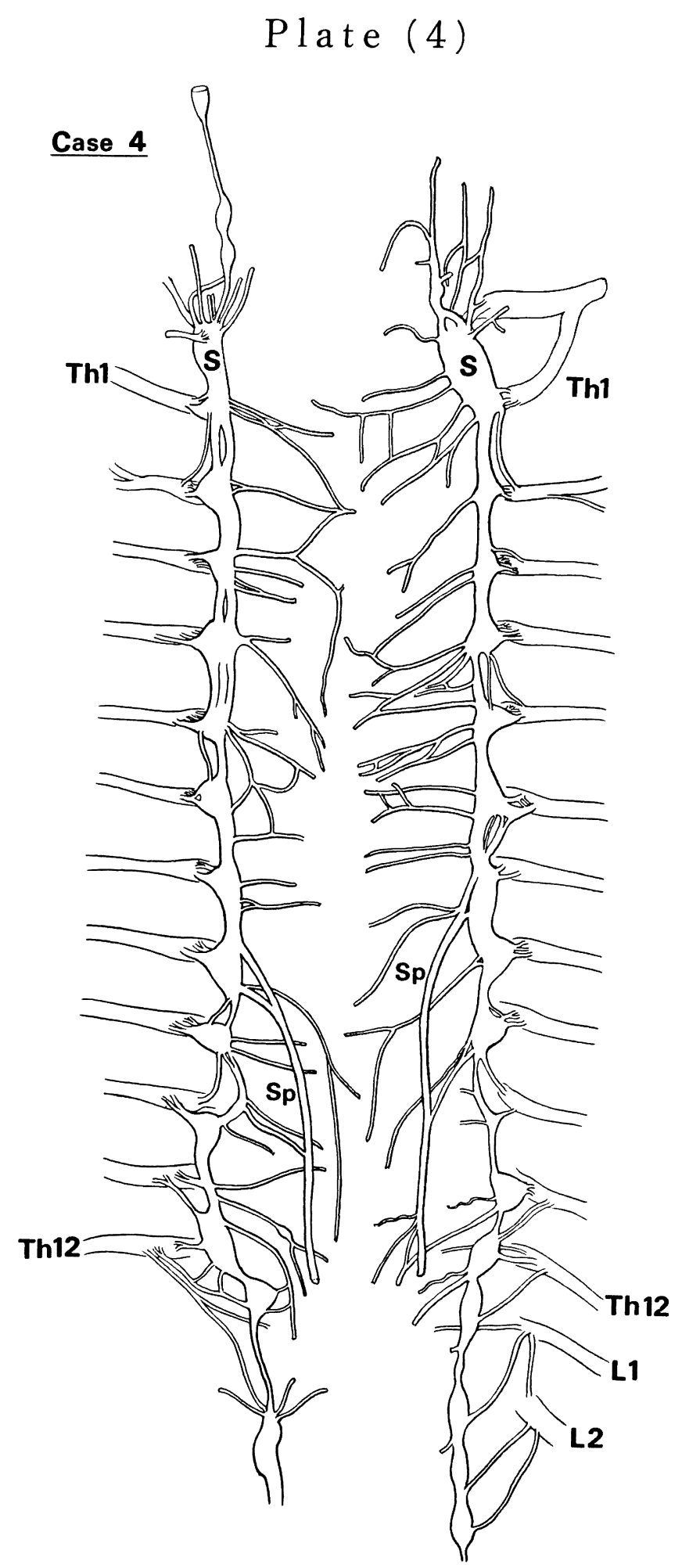


Plate (5)




Plate (6)

\section{Case 6}

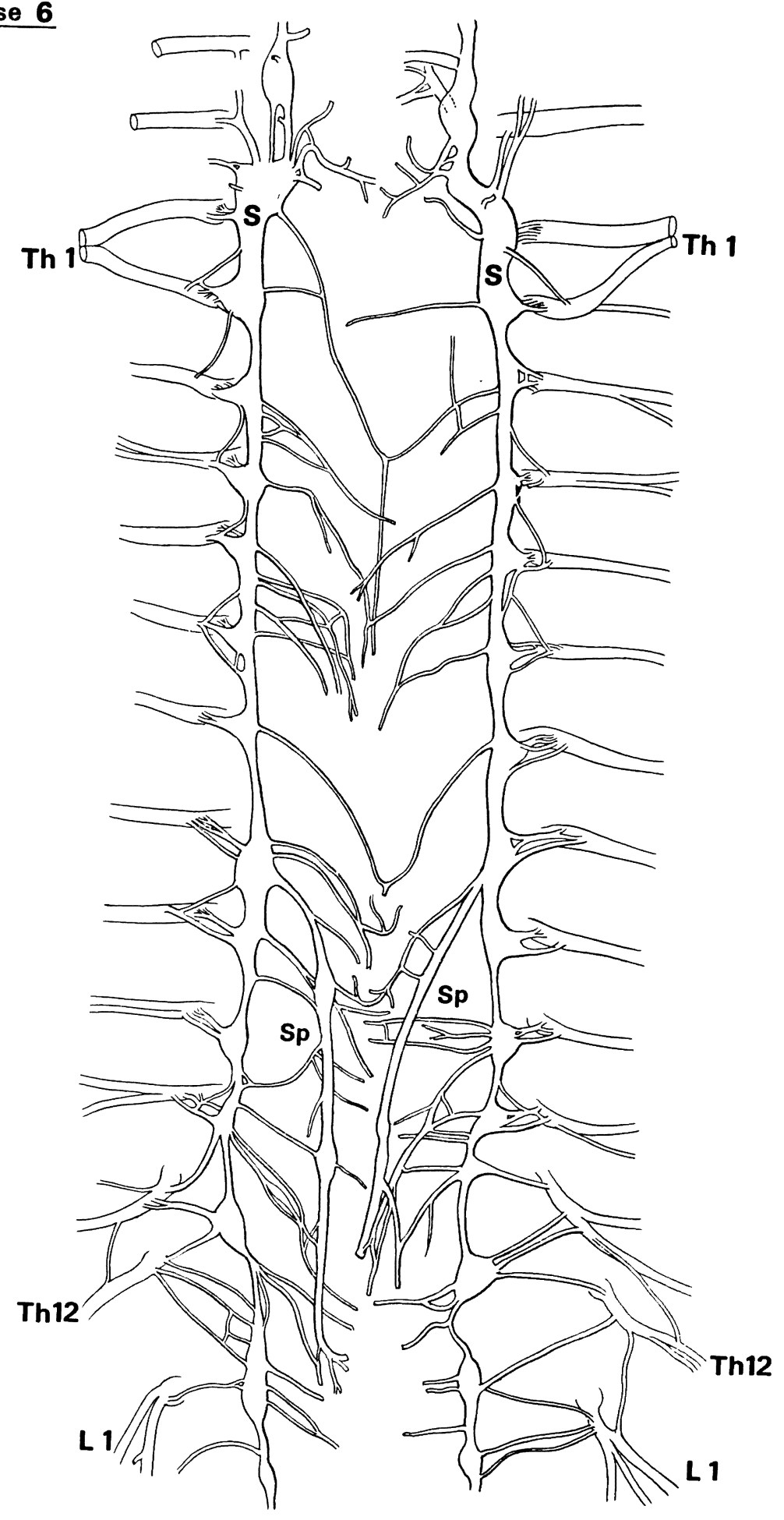




\section{Plate (7)}

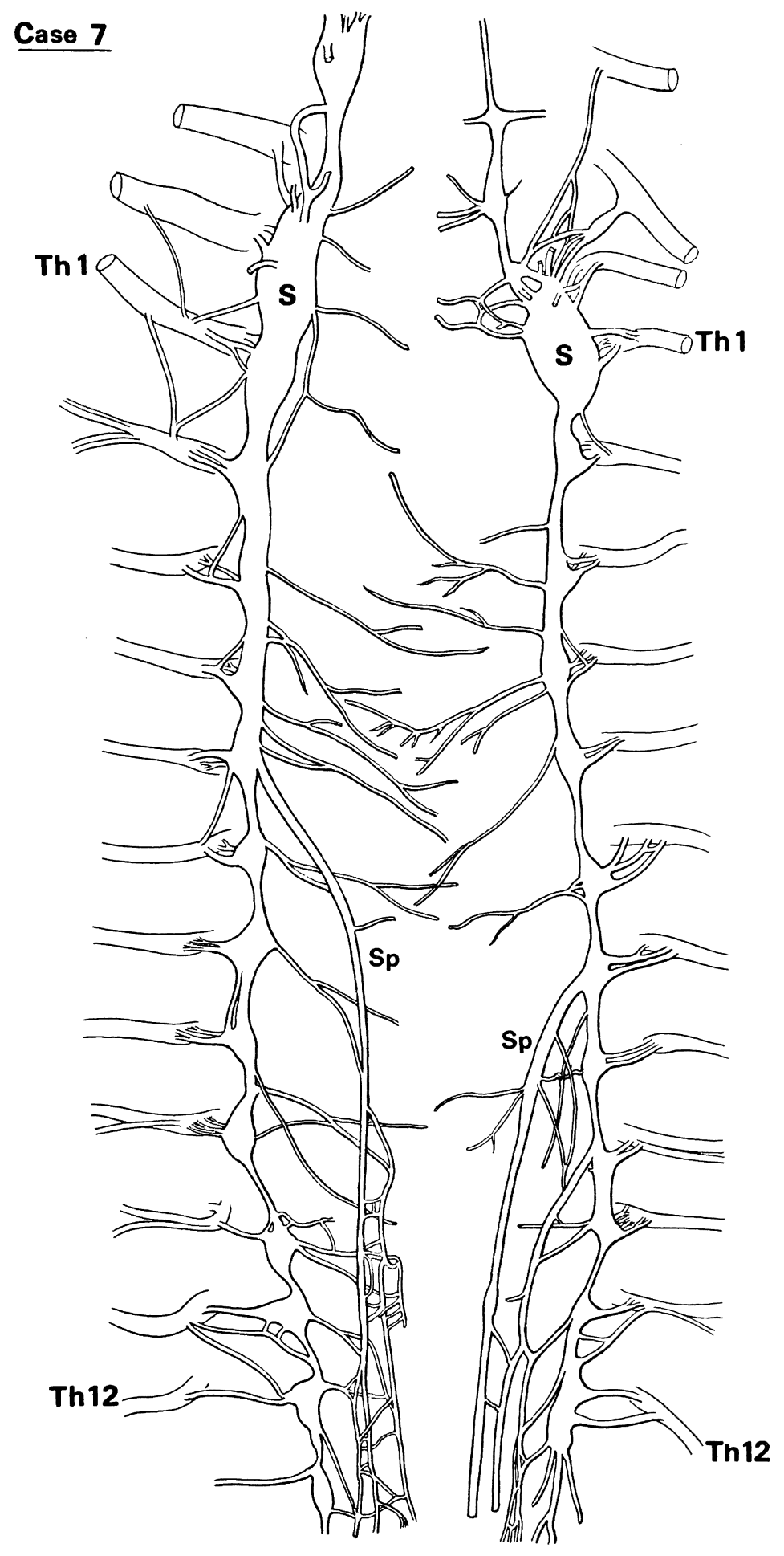




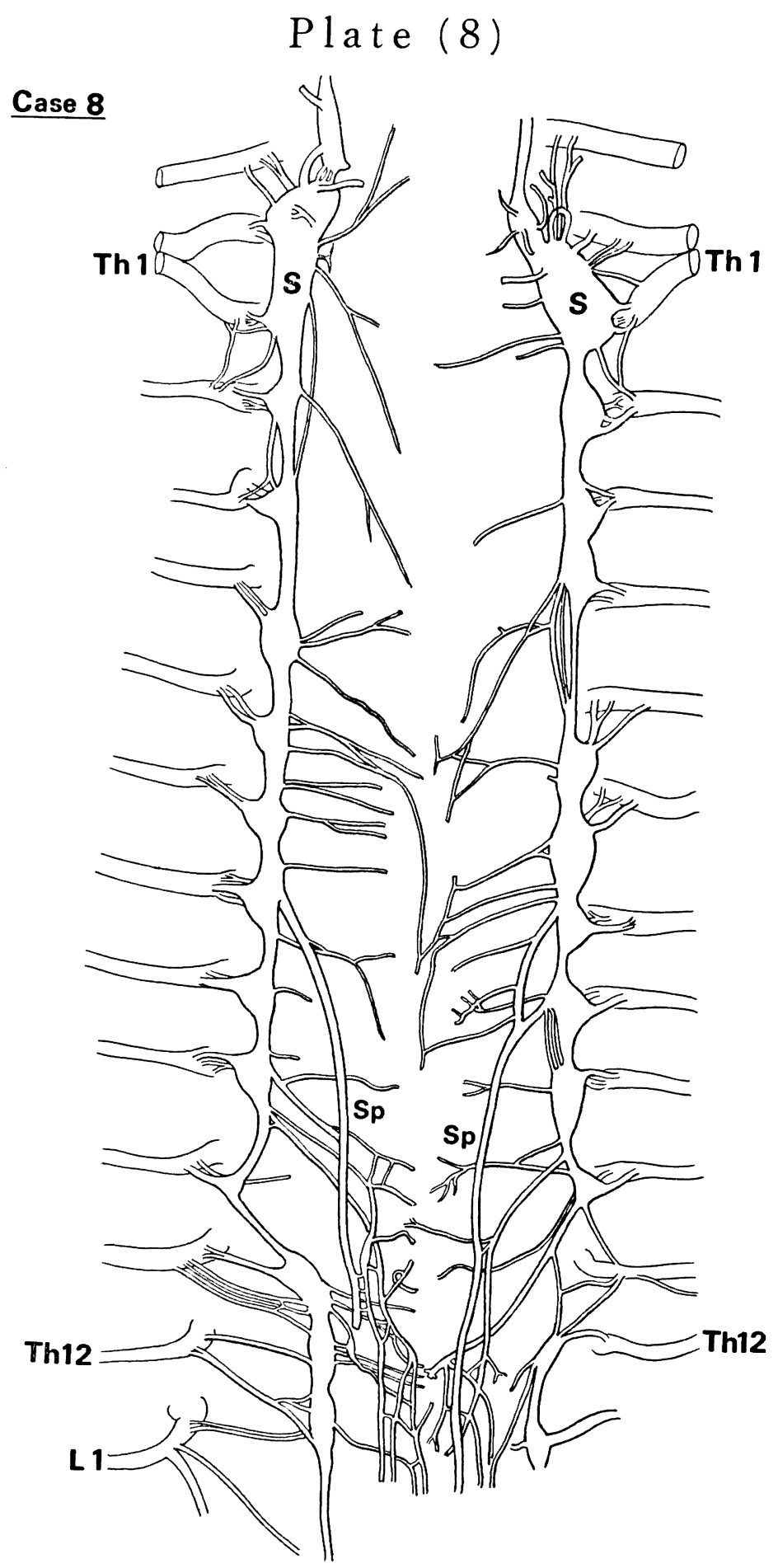




\section{Case 9}

Plate (9)

(455) $-89-$

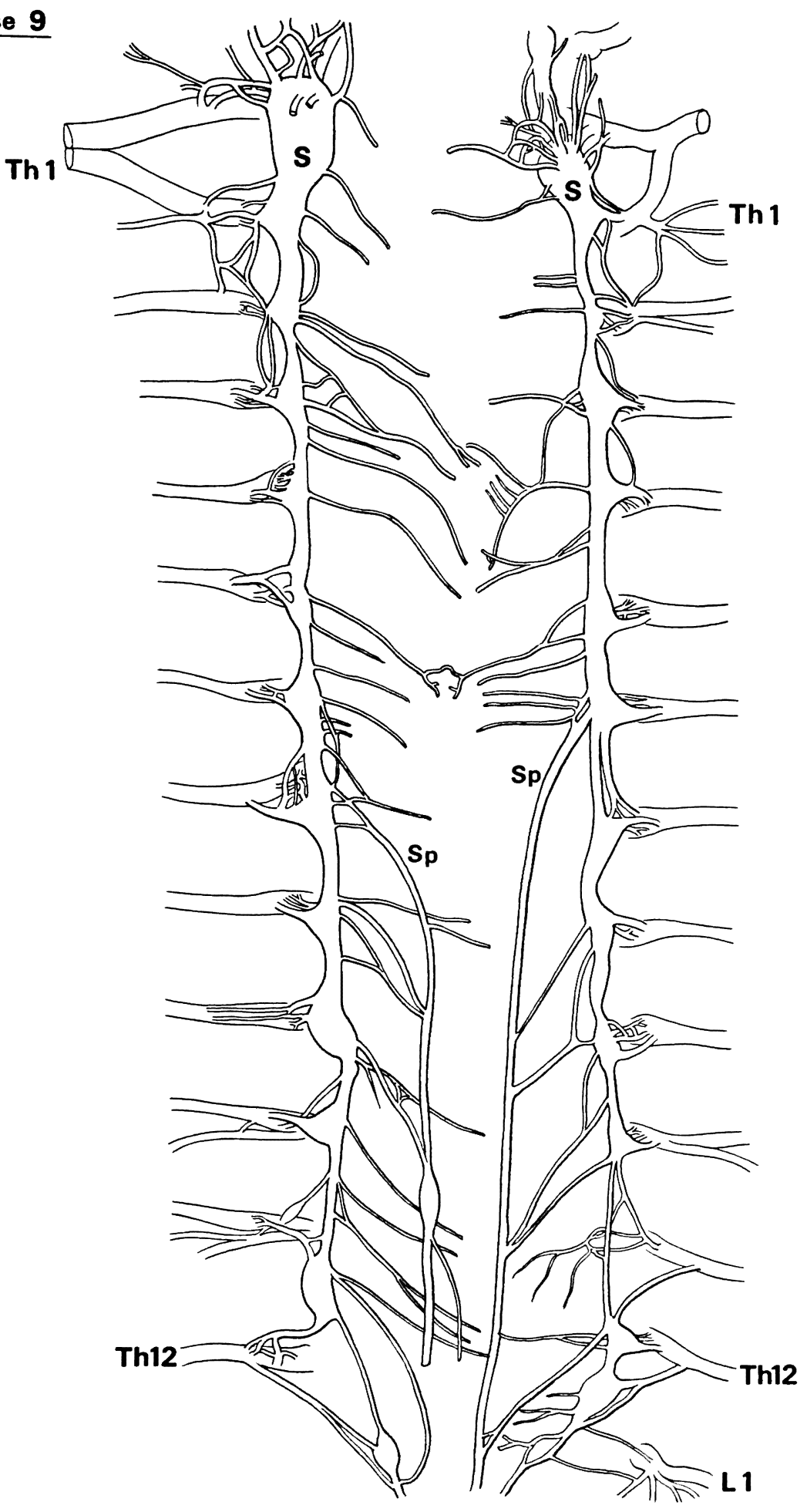


$-90-(456)$

Plate (10)

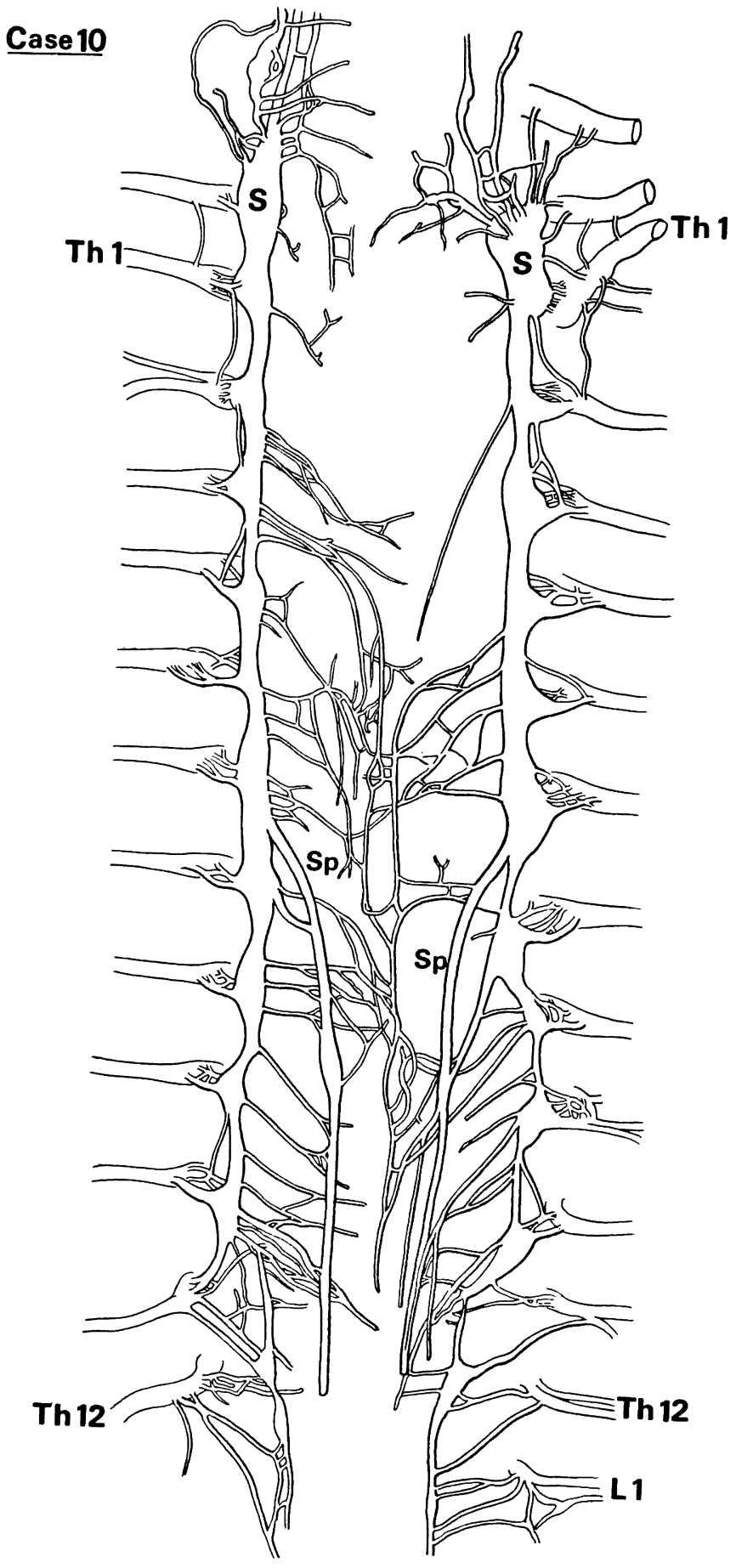


Plate (11)

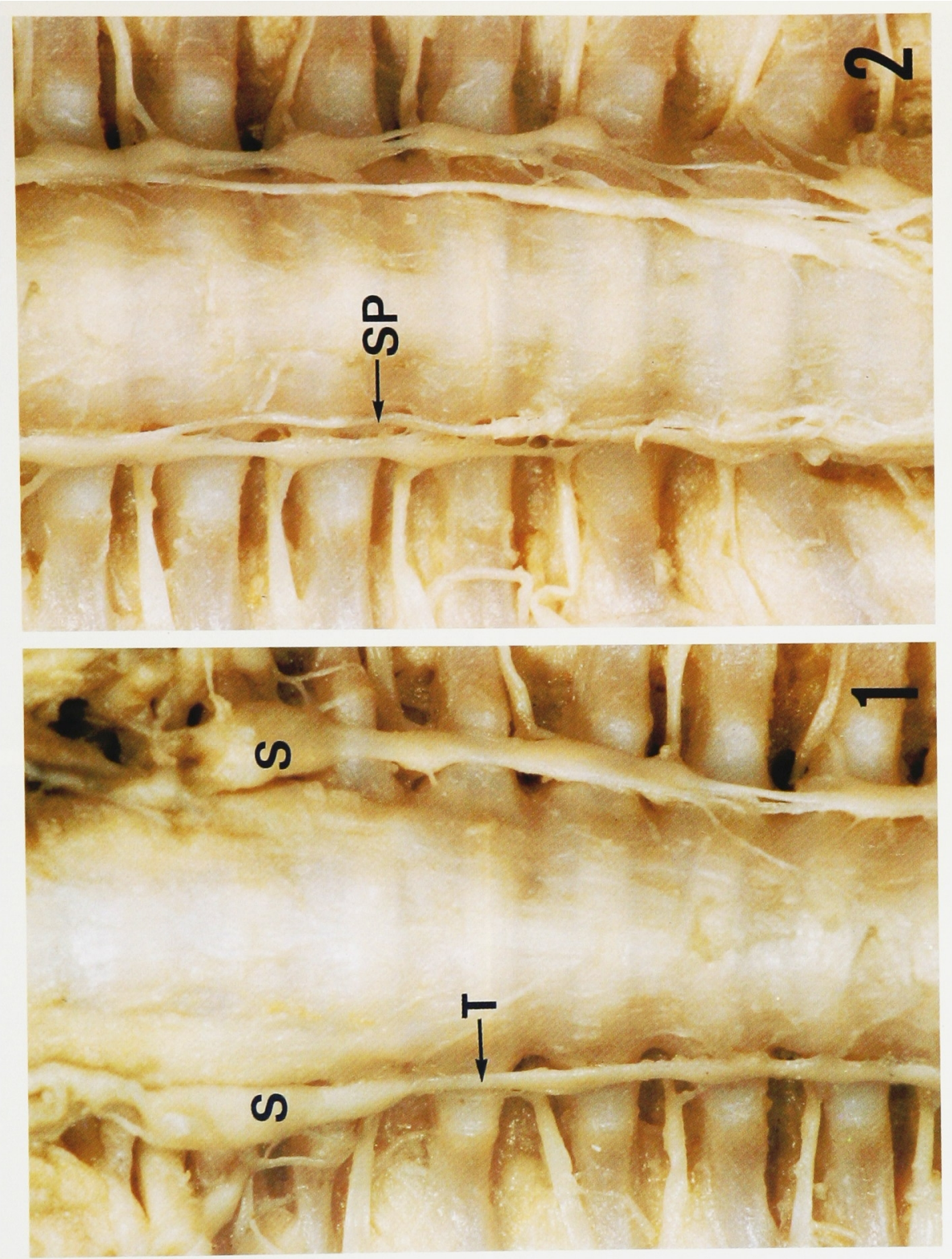


Plate (12)
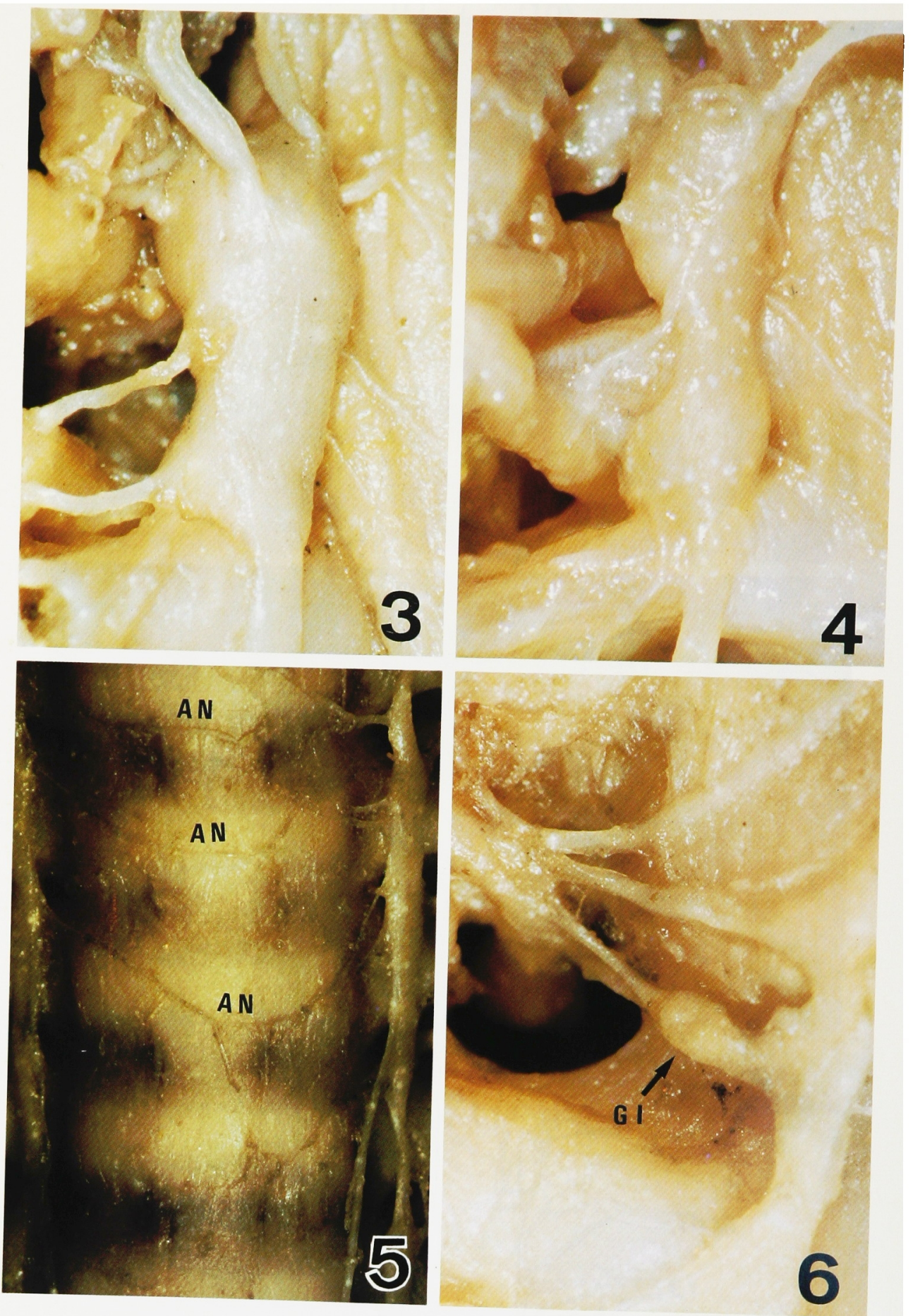
Plate (13)

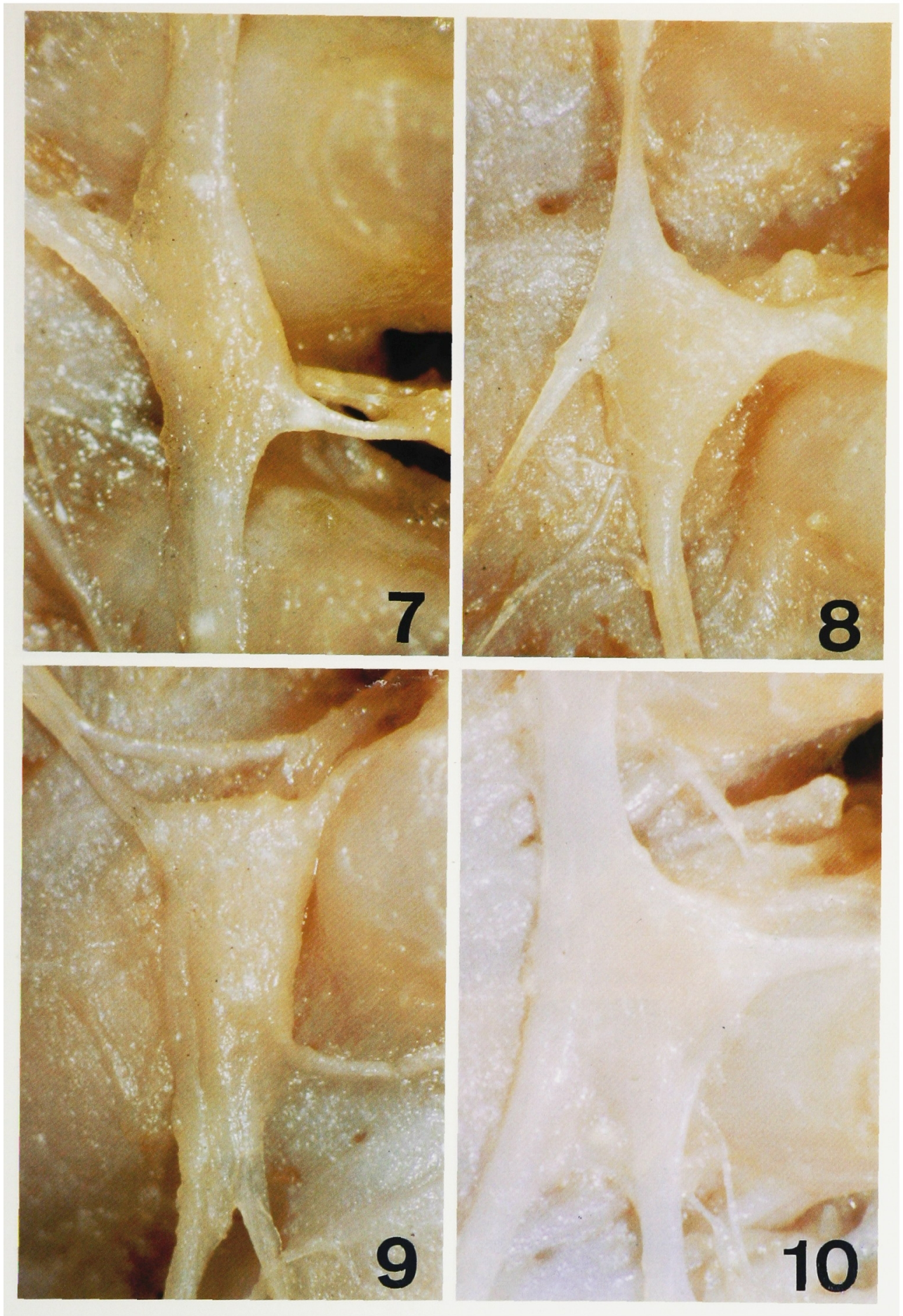


Plate (14)

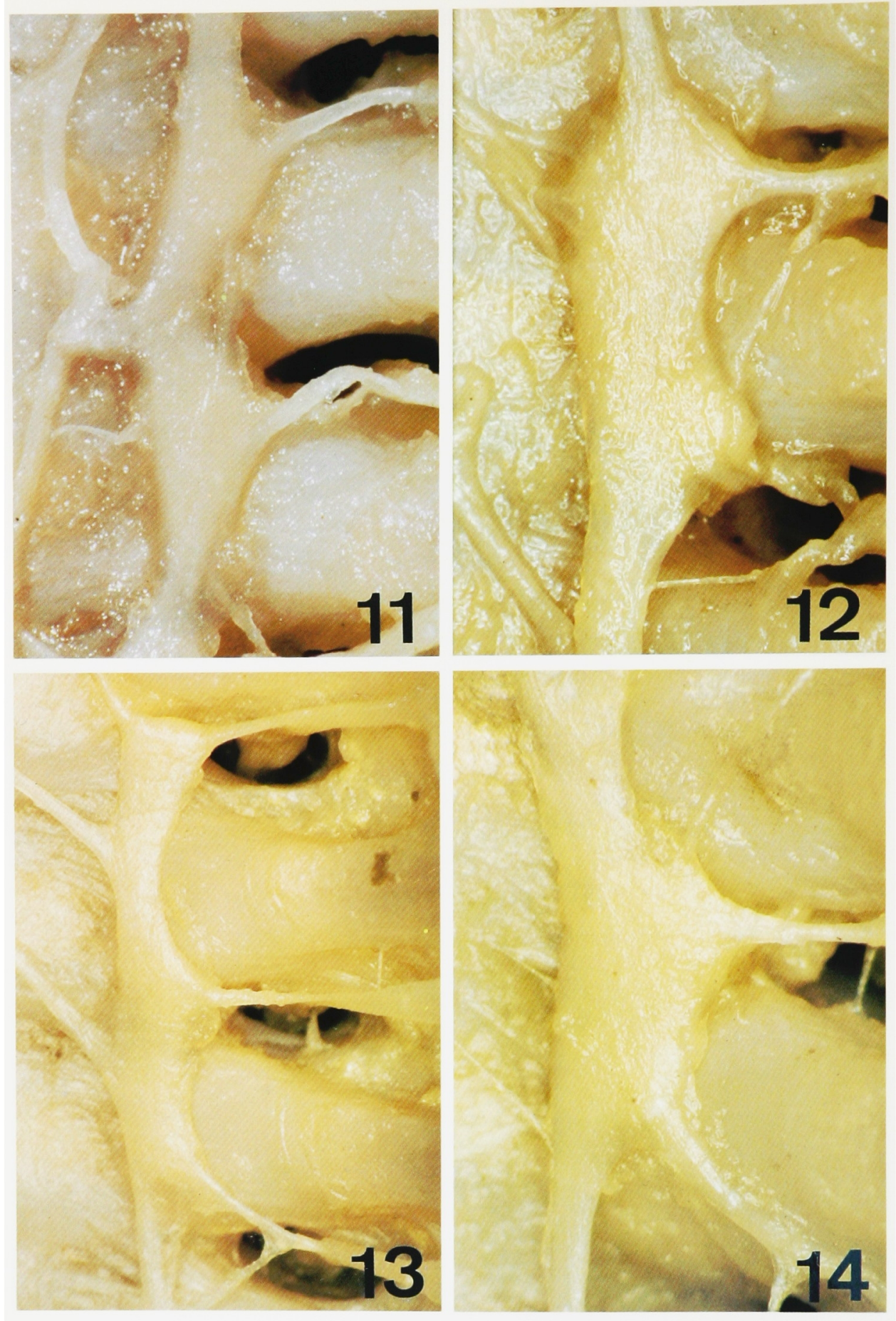




\section{Plate (15)}
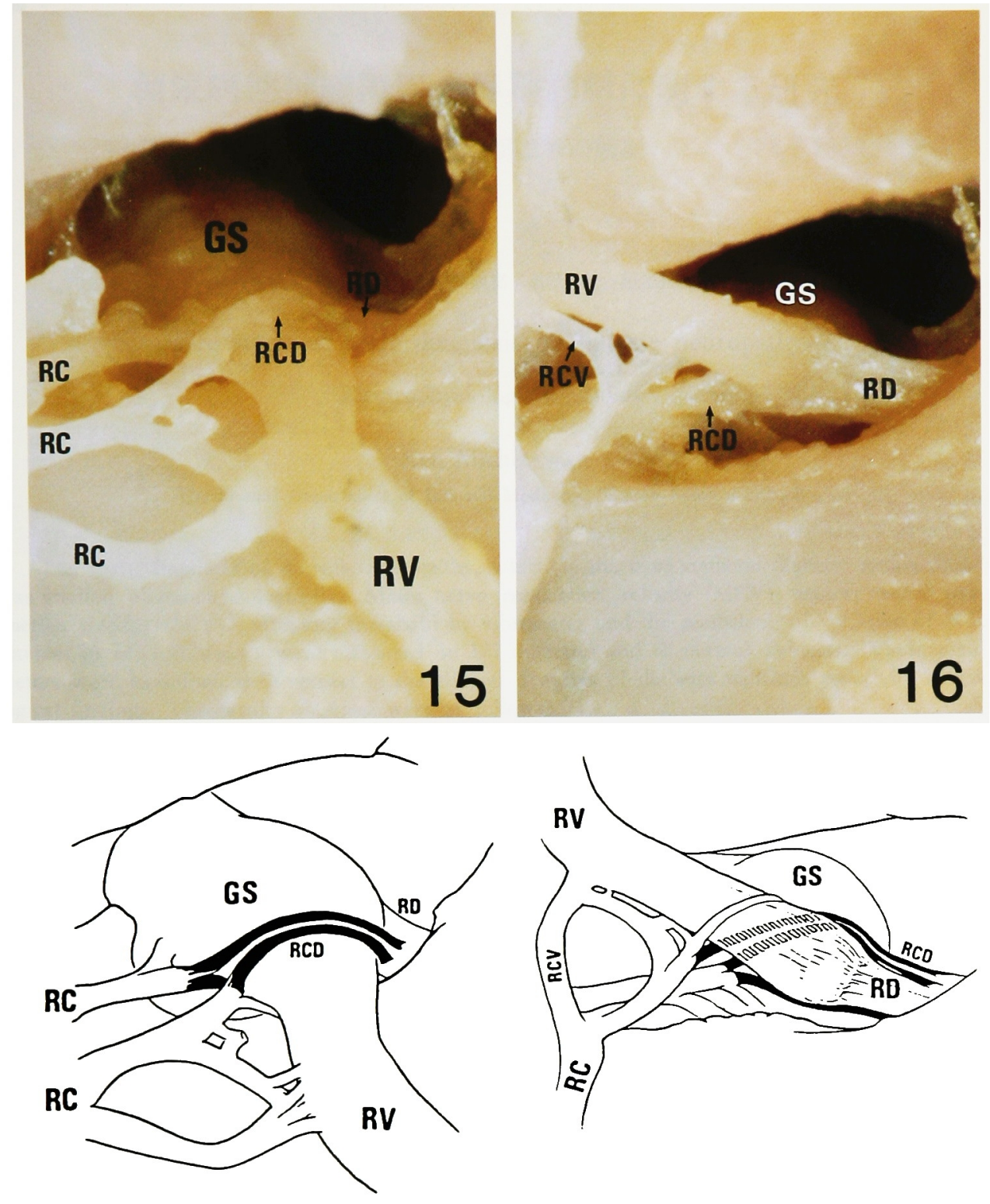

$15^{\prime}$

$16^{\prime}$ 